\title{
LAS FIESTAS ANUALES Y QUINQUENALES DE LA Virgen CANDElaria del SOCORRO DE HuANCHACO: EXPRESIÓN RELIGIOSA DE LOS PESCADORES DE la Costa Norte del Perú
}

Oscar Gabriel Prieto*

\section{Resumen}

Se describen y analizan dos fiestas tradicionales del pueblo de pescadores y agricultores de Huanchaco en la costa norte del Perú. Ambas fiestas, aunque distintas en su origen y significado, guardan profundas raíces en tradiciones ancestrales prehispánicas. En este artículo se las describe detalladamente y además se plantea que dichas fiestas tuvieron por objetivo yuxtaponer el culto al mar como divinidad femenina hacia un culto a iconos católicos femeninos como la Virgen u otras santas.

Palabras clave

Huanchaco, Virgen del Socorro, divinidades femeninas prehispanicas.

\begin{abstract}
In this article, I will study two traditional and modern catholic festivities from Huanchaco, a fishing village located in the North Coast of Peru. Both celebrations are different in its origin but it roots are deeply buried in Prehispanic festivals and traditions. In this paper, I will describe in great detail these catholic festivities. Furthermore, I will argue that it is very possible that Spanish priest adapted traditional Roman Catholic celebrations with Prehispanic festivities in order to overlap both religious traditions.
\end{abstract}

Keywords

Huanchaco, Virgin of the Sorrow, prehispanic female deities.

* Estudiante de Doctorado en Arqueología del Departamento de Antropología, Universidad de Yale.

Correo electrónico: oscar.prieto@yale.edu 


\section{INTRODUCCIÓN}

A parte de la marinera (Romero, F. 1942; Burmester 2000; Recuenco 2007; Romero, G. 2008), es muy poco lo que se sabe acerca de las danzas, música y las fiestas religiosas del Departamento de la Libertad. Salvo algunos pocos trabajos publicados y de fácil acceso (Gillin 1945; Jimenez Borja 1955; Sabogal 1974; Marzal 1977; Schaedel 1989; Casas 1998; Álvarez 2004) no existen tratados que describan y enmarquen en un contexto antropológico la riqueza cultural inmaterial de esta parte del país. La carencia en el plano académico, contrasta con la masiva participación popular en las fiestas religiosas (mayoritariamente católicas) donde se expresa por medio de la práctica, la identidad de los pueblos y por lo mismo, un masivo conocimiento sobre sus nombres, significados y procesos. Un caso común por medio del cual se promocionan y dan a conocer las danzas y música de los pueblos liberteños, es cuando de un pueblo invitan a otro para que participe con sus danzas en las festividades patronales religiosas. Paralelamente existen una serie de concursos y festivales donde se pueden apreciar por lo menos una o dos veces al año, una amplia diversidad de este tipo de manifestaciones culturales.

El 2007 tuve la suerte de poder apreciar un concurso de danzas tradicionales de la Libertad en la pequeña ciudad de Chepén, un emporio comercial del valle de Jequetepeque, aproximadamente a 220 kilómetros al norte de Trujillo. En aquella oportunidad pude aprender sobre las danzas locales y sorprendentemente un sinnúmero de danzas regionales como la "Danza de los Venados" o la "Contradanza", ambas de Huamachuco; la danza de los "Huanquillas" de Chiclin (pueblo del valle de Chicama) o la danza de los "Negritos" de Otuzco. Todas estas danzas no tienen los brillos y trajes de sus contrapartes en el centro o sur del Perú, pero encierran un profundo significado para sus actores, pobladores y para nosotros, los investigadores de las ciencias sociales.

Por citar un ejemplo, la Danza de los Venados toma especial interés dado que en el siglo XVIII fue graficada en una de las tantas acuarelas del ilustrado obispo de Trujillo, don Baltazar
Jaime Martínez de Compañón y Bujanda (1978). Esta danza parece que se realizaba en la sierra de la provincia de Trujillo durante el virreinato, pero fuentes arqueológicas indican que también se realizaba en la costa hacia el siglo VI de nuestra era. En la iconografía Mochica se pueden ver venados antropomorfos danzando en varias comparsas (Donnan y McClelland 1999). Otra representación común es la caza masiva de venados por medio de chacos o rodeos (op. cit.). Sobre el particular Walter Alva halló en la tumba del Señor de Sipan, el atuendo y las armas representados en la iconografía Mochica para realizar dichas actividades, lo cual indica que eran realizadas por miembros de la elite (Alva 1999). Al mismo tiempo, el tema de venados copulando e incluso hembras amamantando a sus crías en expresivas vasijas escultóricas de cerámica Mochica aluden a los ciclos biológicos y regenerativos de esta especie (Donnan 1978). El autor de este manuscrito halló un asta de venado ofrendada en un contexto Lambayeque Tardío en el sitio de San José de Moro en el valle de Jequetepeque (Prieto y Lopez 2007), lo cual indica la importancia de esta especie en las sociedades prehispánicas tardías costeñas. Las fuentes arqueológicas también indican que durante los periodos Preceramico Medio y Tardío (6000-2500 / 2000-1800 a.C.) e Inicial (20001800 / 800-400 a.C) el venado fue una importante fuente de alimento (Miller y Burger 2000) e incluso fue usado como parte de la parafernalia en actividades shamánicas (Elera 1994: 33). Uno de los hallazgos más espectaculares de los últimos años sobre el rol de los venados en tiempos prehispánicos se ha dado en el templo Preceramico de Ventarrón, Lambayeque. Allí, Ignacio Alva ha registrado un mural policromo abstracto en el recinto central del templo que representa una escena de al menos dos venados atrapados en redes (Alva 2010).

Volviendo a la danza actual que se efectúa en la sierra de Huamachuco, hemos notado que esta emula explícitamente el ciclo vital de los venados: nacimiento, crecimiento, paso a la adultez, reproducción y muerte causada por una caza colectiva de humanos. Tomando las reservas del caso, se podrían establecer interesantes paralelos entre el contexto etnográfico y la resu- 
mida evidencia arqueológica indicada anteriormente, en la que claramente se puede ver una continuidad desde las primeras sociedades complejas andinas hasta la actualidad. Esto significa que estas expresiones artísticas contemporáneas son potencialmente valiosas -tomando las prevenciones respectivas- para los estudios antropológicos y arqueológicos.

\section{ENFOQUE DEL ESTUdio}

Desde el 2001 el autor de este manuscrito viene estudiando y recopilando las costumbres y tradiciones del pueblo de Huanchaco, una caleta de pescadores ubicada a 10 kilómetros al norte de la ciudad de Trujillo en el departamento de la Libertad (Prieto 2009). Quizá el rasgo más característico de esta población costeña sea el uso de las balsillas o "Caballitos de Totora" el cual se ha convertido en el símbolo de esta comunidad de pescadores, agricultores y mariscadoras (Fig. 1). Sin embargo hemos podido notar que esta manifestación es solo parte de un gran corpus de costumbres y tradiciones que aún se practican en la intimidad familiar de sus pobladores. Uno de los aspectos más sobresalientes en los pobladores de Huanchaco es la continua práctica de rituales religiosos en sus actividades cotidianas. Estas van desde una sencilla señal de la cruz al momento de ingresar al mar, el bautizo de sus redes (Gillin 1945), hasta complejas romerías anuales y quinquenales con la patrona del pueblo (Virgen Candelaria del Socorro). En este contexto es que se ha tomado interés en las fiestas religiosas de Huanchaco, pues ellas podrían manifestarnos los tabúes, intereses, objetivos y motivos de las celebraciones a nivel comunal. Dado que Huanchaco es uno de los pocos asentamientos costeños en el Perú con una continuidad cultural de aproximadamente 4000 años, entonces el tema de sus ceremonias y los significados detrás de ellas se vuelven sumamente importantes. En esta oportunidad trataremos de las fiestas anuales de la Virgen Candelaria del Socorro y la "Fiesta del Huanchaquito" la única festividad cíclica de la costa norte peruana (Schaedel 1989: 166)

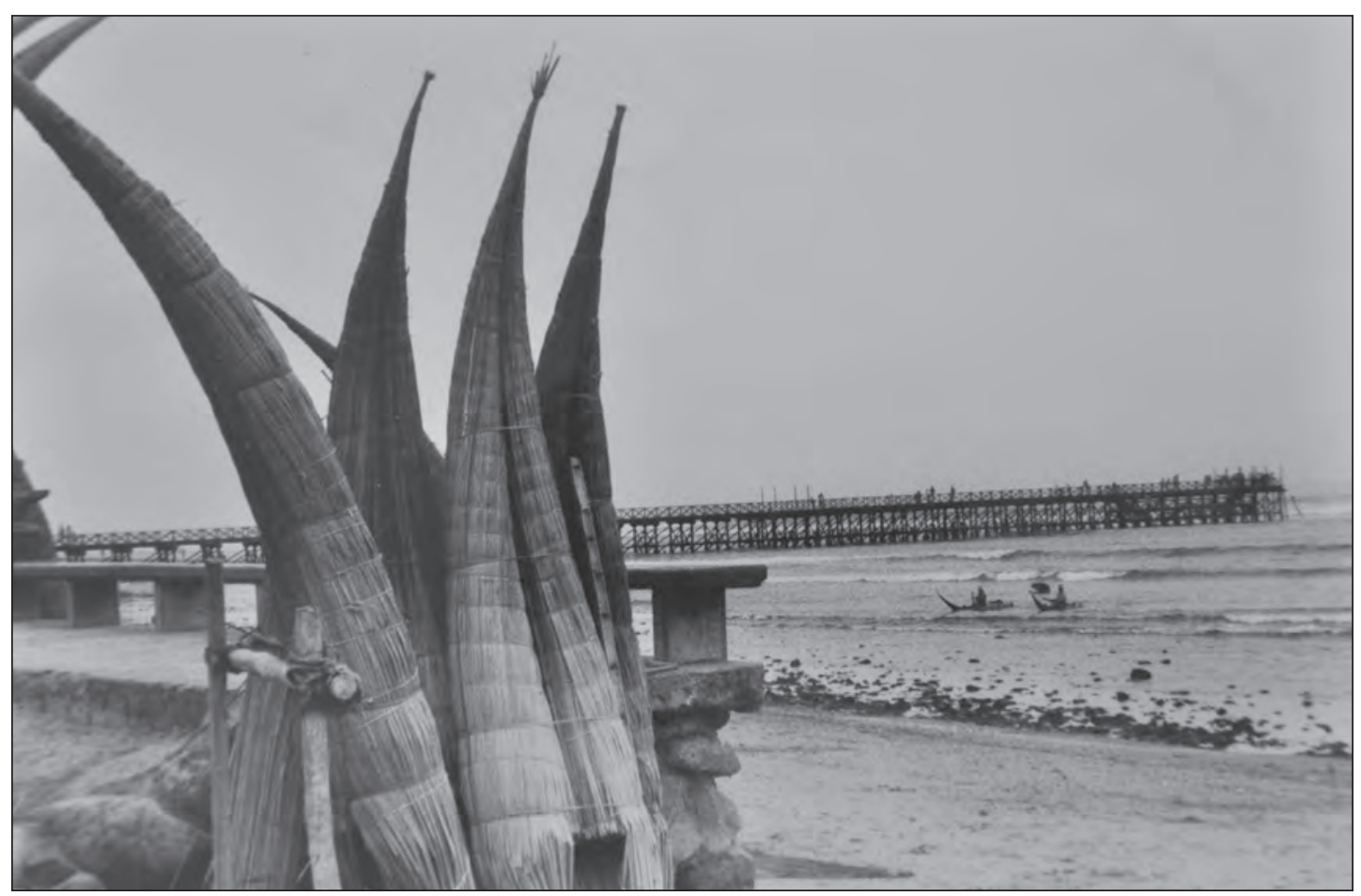

Figura 1. Vista general de la playa donde desembarcan diariamente las balsillas de totora de Huanchaco. Fotografía tomada alrededor de 1984. 
que protagoniza la misma imagen y que se realiza cada cinco años; siendo el eje de la fiesta el viaje y procesión que realiza la imagen desde el pueblo de Huanchaco hasta la ciudad de Trujillo. Antes de ingresar a describir estas fiestas, revisaremos brevemente el rol y significado de la Virgen María en el contexto Andino.

\section{LA ViRgen María en El PROCESO HISTÓRICO DE ACULTURACIÓN EN LOS ANDES}

Desde el descubrimiento de América, la Virgen María estuvo presente en las acciones de los europeos. No es coincidencia que Cristóbal Colón llamara a su carabela de mando "Santa María" pues la expedición fue consagrada a la madre de Dios (Vargas Ugarte 1947: 24). Del mismo modo, durante la conquista de México y los territorios adyacentes, el culto a la Virgen cumplió un papel preponderante, especialmente entre las poblaciones costeras de la península de Yucatán (Carrillo y Ancona 1949). Cuando Pizarro y sus huestes llegaron al actual territorio peruano, sus actos de conquista fueron igualmente consagrados a María (Vargas Ugarte 1947; Damian 1995). Tras el trauma y desorden de los primeros años de la conquista del Imperio de los Incas el culto a la Santísima Trinidad, a María y a los Santos se extendió rápidamente por todos los Andes Centrales (Damian 1995). En muchos casos hubo en realidad una yuxta- posición de cultos, reemplazando antiguas divinidades andinas por sus semejantes católicos, lo cual se basaba en el género, en la coincidencia de las fechas de las celebraciones, en las semejanzas de sus poderes metafísicos, etc. Así, los indígenas asociaron rápidamente la idea de una divinidad femenina en la religión católica y la relacionaron con el culto a la tierra (Pachamama) y al mar (Mamacocha) (op. cit.). Es por ello que durante el virreinato se construyeron múltiples Santuarios así como altares en templos y capillas dedicados a la Madre de Dios. A ello debe agregarse la marcada devoción de los ibéricos por las diferentes advocaciones de la Santísima Virgen y los milagros que estos le adjudicaron durante el proceso de conquista del imperio de los Incas, como su milagrosa intervención durante el sitiado del Cuzco por las huestes de Mano Inca. En el caso de la costa norte del Perú, parece que hubo una marcada intención de asignar a todos los pueblos de pescadores del litoral, una advocación de María u otra santa femenina del panteón católico. Tal como indicamos en la Tabla I, prácticamente todos los pueblos de pescadores llevan nombres alusivos a deidades femeninas Católicas o tienen por deidad tutelar a una Virgen o Santa (Tabla I). Al parecer, más que una coincidencia, es posible que este deliberado acto tenga como telón de fondo el hecho que entre las poblaciones prehispánicas de pescadores había un extendido culto a divinidades femeninas asociadas al mar y su productividad. Por lo

Tabla I

\begin{tabular}{|c|c|}
\hline Nombre de la caleta & Advocación de la Virgen o Santa Patrona \\
\hline Puerto del Callao & Virgen del Carmen \\
\hline Puerto de Supe & María Magdalena \\
\hline Caleta Vidal & Virgen del Carmen \\
\hline Huarmey & Virgen del Rosario \\
\hline Puerto Casma & Virgen del Carmen \\
\hline Huanchaco & Virgen de la Candelaria del Socorro \\
\hline Santiago de Cao & Virgen del Rosario \\
\hline Magdalena de Cao & María Magdalena \\
\hline Puerto Eten & Virgen Purísima \\
\hline Caleta Santa Rosa & Santa Rosa de Lima \\
\hline
\end{tabular}


tanto, los españoles simplemente reemplazaron cultos manteniendo el género de las divinidades con el objeto de facilitar la evangelización. El autor de este manuscrito cree que esto se dio gracias a la experiencia previa de los conquistadores en Centro América, donde los españoles rápidamente aprendieron sobre la tendencia religiosa de los pueblos y la efectividad de los iconos católicos en ciertos contextos.

Varios trabajos arqueológicos y etnohistóricos, han demostrado la importancia de las divinidades femeninas entre los pobladores de la costa peruana y especialmente entre aquellos de las poblaciones de pescadores. En la iconografía mochica del valle de Jequetepeque se puede apreciar para la fase tardía, la presencia de mujeres que ingresaban al mar para realizar rituales en grandes balsas de totora (McClelland 1990; McClelland et al. 2007) y posteriormente, durante el periodo Chimú, se ha identificado en la cerámica una divinidad femenina asociada a la fertilidad y abundancia (Mackey 2001) mientras que la misma divinidad parece estar también representada en los murales de los palacios de Chan Chan (Campana 2008). En la costa sur, región de Nasca se ha propuesto la existencia de una divinidad femenina del mar representada por la ballena asesina de la iconografía de Nasca (Morgan 1988: 327), mientras que en la costa central, María Rostworowski ha identificado una divinidad prehispánica femenina a la cual los pescadores asignaban el origen de los peces y la fertilidad del mar (Rostworowski 2004). Esta última tenía su santuario en Pachacamac y su nombre curiosamente evocaba un ave (op. cit.). Adicionalmente, los incas reconocieron la importancia del mar, y le asignaron un carácter femenino al denominarle la "Mama Cocha" siendo la oposición de la "Pacha Mama" o madre tierra (Damian 1995). La importancia del mar era reconocida por ser el origen de las lluvias y todas las fuentes de agua en la sierra andina (Arguedas y Duviols 1966). Por esta razón se le ofrendaban conchas de Spondylus y otros bienes valiosos durante toda la historia prehispánica (Paulsen 1974).

El arraigo a las antiguas creencias prehispánicas y católicas que existe hoy en día fusiona- das entre los pescadores costeños, hace que estos (especialmente en la costa norte) consideren al mar como si fuera de género femenino, pues le denominan con respeto La mar ${ }^{1}$." Esta denominación la usan, hoy en día, los pescadores que por lo general superan los 60 años de edad. En una visita etnográfica que realizamos el 2009 entre los puertos de Huacho en Lima y San José en Lambayeque, se hizo la pregunta del por qué le llamaban al mar La mar. Las respuestas fueron más que sorprendentes. La más sencilla se refirió a que el mar es como la mujer: a veces se pone "muy brava" como a veces se pone "quietecita" mientras que la respuesta más elaborada argumentó "... porque la mar se enferma (menstrua) como una mujer..." Esta respuesta fue explicada en referencia a las mareas rojas ocasionadas por la sobreproducción de cierto tipo de fitoplancton. En otros casos es beneficiosa porque propicia la buena pesca y la presencia de grandes cardúmenes. En otros casos sirve como una limpieza que va despejando de todo desperdicio las aguas marinas. En ambos casos es relevante que el mar sea visto como una mujer, dada su conducta o las expresiones físicas que este experimenta. Argumentamos que estas creencias son definitivamente de reminiscencia prehispánica, dado que esto no tiene antecedentes en las creencias católicas europeas a pesar que en la concepción ideológica católica el mar está asociado a la Virgen María (Trens 1946). En un trabajo previo, Antonio Rodriguez Suy-Suy había registrado que en la caleta de Puerto Morín del valle de Viru, los pescadores comían y ofrendaban alimentos, chicha y oraciones a ciertos islotes cerca de las playas a los cuales denominaban Comadrita Shusha pues era ella quien determinaba la buena o mala pesca (Rodriguez Suy-Suy 1997: 74). Del mismo modo tenían un ritual en el cerro Guañape en el que todo el pueblo iba a merendar a dicho paraje tocando música y bailando. Mientras comían y tomaban chicha le decían al cerro: "... para que nos des tus pescaditos, para nuestra comidita..." Luego hacían una suerte de pesca ritual con un chinchorro y se repartían lo obtenido (op. cit.: 74)

1 Debe indicarse que en varios pueblos de España también se le denomina La mar. 
El mar era (y es) entonces visto como una divinidad femenina que propiciaba la producción no solo de la playas sino también de la tierra a través de las fuentes de agua dulce, las cuales se creían que estaban conectadas de algún modo con el mar (Arguedas y Duviols 1966). Cuando los españoles llegaron a las costas peruanas, debieron notar rápidamente la importancia que tenía el mar en el plano simbólico para los locales y por esa razón es que creemos que adaptaron astutamente las creencias locales de cada pueblo con divinidades católicas femeninas. Uno de esos casos fue Huanchaco en donde se instauró el culto a la Virgen Candelaria.

\section{La Advocación de la Candelaria}

La advocación de la Candelaria se basa en que cuarenta días después del nacimiento de Cristo, María cumplió con el rito judío de la purificación, que sigue al alumbramiento, dando origen de este modo a la Fiesta de la Purificación, más conocida como Candelaria (Trens 1946; Vargas Ugarte 1947). Su día de celebración es el 2 de febrero. Es interesante señalar que en las Islas Canarias, existe una gran devoción a la Virgen Candelaria. Coincidentemente, Las Canarias era la última parada en la cual las naves que se dirigían a las Américas se detenían antes de iniciar la travesía en mar abierto. Así, los viajeros siempre se encomendaban a esta advocación de la Virgen y de allí la preferencia hacia ella en el Nuevo Mundo (Málaga 2000). En el continente Americano el culto a la Candelaria es muy extendido y está presente en países como México, Guatemala, Puerto Rico, Venezuela, Colombia, Chile, Bolivia, Argentina y Uruguay (Vasques et al. 2002: 61-3). En el Perú existen varias imágenes de Candelarias sobre todo en el sur andino, principalmente en el departamento de Arequipa (donde hay hasta 25 imágenes) (Málaga 2000) y en el departamento de Puno donde sus celebraciones son una de las fiestas religiosas más coloridas y multitudinarias del mundo moderno (Vasques et al. 2002). Cabe indicar que la Virgen Candelaria del Socorro de Huanchaco, es la única imagen Candelaria de la Costa Norte del Perú.

\section{La Virgen Candelaria del Socorro DE Huanchaco, su ORIGEN Y SU NOMBRE}

La imagen de la Virgen Candelaria que llegó a Huanchaco es una talla de madera de caoba, probablemente de la escuela de Sevilla y de aproximadamente $1.20 \mathrm{~m}$ de alto (Fig. 02). Un lamentable incendio en 1887 afectó seriamente la escultura, la cual fue restaurada posteriormente. Irreparablemente, se perdieron los detalles originales de los diseños y colores de su vestido el cual está actualmente pintado de color celes$t^{2}$. La imagen sostiene en su mano izquierda otra escultura en madera caoba del Niño Dios, el cual es una imagen de vestir. La tradición popular también sostiene que la imagen fue hecha a imagen y semejanza de la madre del Rey Carlos I de España, la famosa Juana la Loca. Sin embargo no existe ningún documento histórico ni mucho menos existe una correlación sincrónica entre la manufactura de la imagen y la vigencia del reinado de Carlos y su madre. Actualmente ambas imágenes (La Virgen y el Niño) visten pelucas hechas con cabelleras femeninas donadas por las jóvenes del pueblo y también coloridos mantos donados por los devotos.

No se sabe la fecha exacta de la llegada de esta imagen a las costas de Huanchaco, aunque el acervo popular asegura que se trata de una de las imágenes más antiguas de toda América del Sur. Actualmente se celebra la llegada de la imagen (el cual es también el día de su fiesta patronal) el 2 de febrero, sin embargo, esta fecha es en la que en el mundo católico se celebra las fiestas de la Candelaria. Es probable que la imagen haya arribado entre 1540 y 1560 . Cabe mencionar que de acuerdo a los escasos datos que se tienen de la fundación de Trujillo, los sacerdotes que acompañaron el acto y el posterior trazado de la ciudad fueron monjes mercedarios y dominicos. Bajo esta perspectiva, las imágenes o al menos las advocaciones de la Virgen que llegaron primero a esta zona debieron ser la Virgen de las Mercedes o la Virgen del Rosario, pues ambas son de la devoción de dichas órdenes religiosas. Dado que Huanchaco fue sujeto al curato de la orden de los franciscanos, fueron

2 Hacia el 2005 la imagen tenía el vestido pintado de color blanco. 


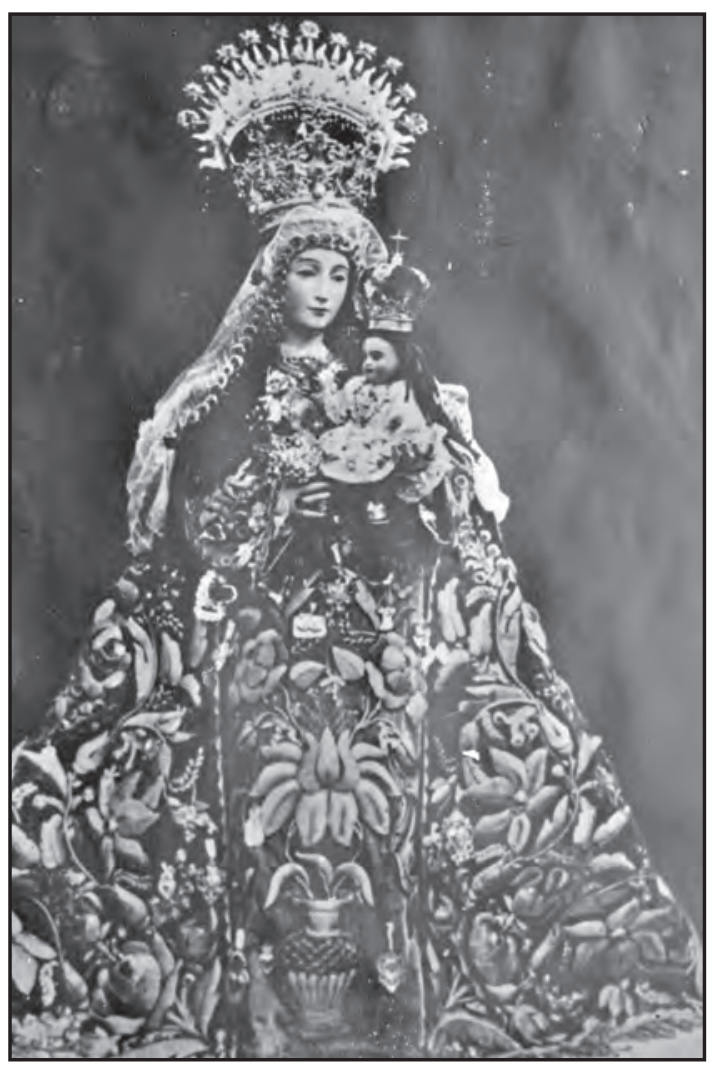

Figura 2. Imagen de la Virgen Candelaria del Socorro de Huanchaco.

ellos quienes comenzaron la evangelización de sus habitantes y quienes debieron mandar traer la imagen de la Virgen Candelaria.

Juan Castañeda, ha llamado correctamente la atención al indicar que el nombre de Socorro fue tardíamente introducido para denominar a la Virgen Candelaria de Huanchaco. En los documentos de los siglos XVI y XVII se le denominaba Virgen de Huanchaco o Nuestra Señora de Huanchaco (Castañeda ms.). En la crónica del padre franciscano Eugenio Lanuza y Sotelo (1998) se indica un pasaje en el cual la Virgen de Huanchaco era denominada Nuestra Señora de Guanahaca que significaba en la lengua local "cosa fuerte y brava" debido al fuerte oleaje que Huanchaco tiene y que en épocas virreinales dificultaba el desembarco de los bergantines. Según este cronista la Virgen se le apareció en sueños a una anciana a la cual le pidió que la dejen de llamar así y le denominen "Nuestra
Señora del Socorro, mansa cordera del valle". Proponemos que Guanahaca es la forma en que los pescadores locales pronunciaban la palabra que los españoles denominaban "Huanchaco", por lo tanto, puede tratarse de un fino detalle hecho por Lanuza y Sotelo para aproximarse más a la forma correcta del nombre usado por los nativos de Huanchaco. Juan Castañeda cree que el nombre de Guanahaca es un error tipográfico del padre Lanuza y Sotelo quien quiso escribir en realidad "Huanchaco" (Juan Castañeda, comunicación personal 2007). En todo caso esta discusión queda abierta y a la espera de nueva evidencia procedente de archivos etnohistóricos. Lo importante aquí, es resaltar que el nombre del "Socorro" adquirido por la imagen es posterior y que originalmente llegó como "Virgen Candelaria" o simplemente "María." Posteriormente fue denominada por los locales "Nuestra Señora de Huanchaco" o "Nuestra Señora de Guanahaca" y finalmente adquirió el de "Nuestra Señora del Socorro." En la actualidad tiene oficialmente el nombre de "Virgen Candelaria del Socorro de Huanchaco," mientras que las familias de pescadores le denominan "La Patrona," "La Mamita del Socorro," "La Madre," "Socorrito," o "Virgen del Socorro."

\section{La Llegada Mítica de la Virgen Candelaria a Huanchaco}

La tradición popular ha creado, a lo largo de los años, una serie de leyendas en torno a la llegada de la imagen de Nuestra Señora. En esta ocasión, utilizaremos la narración ofrecida en 2001 por el pescador Mercedes Díaz quien era el poblador con mayor edad en el pueblo de Huanchaco. Lamentablemente, don "Meche" como cariñosamente le llamábamos, falleció el año 2004. Esta versión puede ser contrastada con otras impresas anteriormente, pero el autor de este manuscrito cree que es la más completa y rica en detalles en relación a las abreviadas versiones previamente publicadas (García 2001). La versión completa de esta leyenda se encuentra como anexo a este manuscrito y debe atribuírsele no a este autor, sino a don Mercedes Díaz. 
En el caso de Huanchaco, la llegada de la imagen de la Virgen Candelaria se enmarca en una leyenda de arraigo popular en la cual se enfatiza su arribo por mar desde España a las playas de Huanchaco. Si bien es cierto este arribo por el mar tiene lógica, dado que Huanchaco era el puerto de Trujillo y que cualquier carga de España llegaba generalmente por barco, entonces no tendría nada de raro o especial que la imagen haya llegado por este medio. Sin embargo se ha planteado de una manera muy interesante la relación que podría haber entre la llegada por mar de esta imagen, con el arraigado mito prehispánico de la llegada de Tacaynamo (en las costas del valle de Moche) o Naymlap (en el valle de Lambayeque) (Alva Mendo 2005). Alva Mendo ha sugerido que la llegada por mar de la Virgen Candelaria a las playas de Huanchaco trató de suplantar el mito prehispánico del héroe civilizador Tacaynamo (op. cit.). Si esto es válido, entonces estaríamos ante otro caso de superposición de roles de divinidades prehispánicas por católicas. Sin embargo lo que no queda claro, es como se manejó el cambio de una divinidad masculina (héroe civilizador) por otra femenina (Virgen María).

El autor de este manuscrito cree que además de esta propuesta, es posible que la llegada de la Virgen por mar, señale la manipulación de los sacerdotes españoles para adoctrinar a los pescadores locales, cambiando a la divinidad femenina marina por la Virgen misma. La diferencia en nuestra propuesta es que no se quiso reemplazar el mito de Tacaynamo o Naymlap, sino que se quiso demostrar el poder que tenía la Virgen María y por lo tanto que ella podría cumplir las mismas funciones que la divinidad femenina marina prehispánica.

Esta propuesta se basa en que de acuerdo a la versión de la leyenda de don Mercedes, esta realiza dos milagros claves: el primero se da cuando se está tratando de transbordar el gran cajón que contiene la imagen de la Virgen del barco hacia el patacho ${ }^{3}$ (balsa) de totora hecho

3 Patacho es una derivación local de la palabra española "Patache" que significa balsa o barca. Así, Patacho no es una palabra prehispánica como se ha supuesto. Agradecemos la aclaración hecha por Juan Castañeda. especialmente para la ocasión. Según la versión que citamos, cuando se está haciendo esta maniobra, el mar que estaba embravecido, se calmó repentinamente. A parte de la coincidencia y la facilidad que propició para terminar con la operación, en el contexto de Huanchaco el mar calmo o "lagunita" como refiere la leyenda, propicia siempre una buena pesca, por lo que es evidente que a penas la Virgen entra en contacto con el patacho hecho por los huanchaqueros se produce una identificación de sus poderes al propiciar las condiciones necesarias para una buena pesca. En el contexto de la leyenda, esto debió ser reconocido por los pescadores inmediatamente y debió generar un sentimiento de aceptación paulatina cuando la leyenda fue contada y transmitida en principio por los frailes españoles y luego por el acervo popular. El segundo milagro se da en el contexto de la playa, donde una vez desembarcada la imagen, ésta cura a una niña de ceguera. Este segundo milagro está estrechamente relacionado al objetivo de los españoles de crear una nueva fe entre los pobladores, siendo la niña, como futura mujer, la que despierta y sale de su ceguera (ceguera religiosa?) y adopta la nueva fe (lo cual es representado metafóricamente por el milagro de recobrar la vista). Como vemos, la leyenda está orientada a crear una nueva conciencia dando un mensaje subliminal y por otro lado garantiza a los pescadores que la Virgen va a cumplir con propiciar buena pesca pues tiene el poder de calmar las aguas para que los pescadores entren en sus balsas y los peces entren a la bahía para que estos puedan ser capturados por sus redes. Sobre el particular, cabe destacar que diariamente los pescadores invocan el nombre de María cuando ingresan al mar en sus balsillas, pidiendo en principio seguridad y en segundo lugar una buena pesca. Hemos notado también que en las misas que celebran los pescadores y en las procesiones anuales de la imagen, las peticiones más recurrentes son propiciar la buena pesca, evitar que se aleje el pescado de Huanchaco por el friaje (aguas frías), y mantener a salvo a los pescadores durante las faenas de pesca en el mar. Cabe mencionar aquí que nunca se pide a 
la imagen que aleje las aguas tibias, pues en realidad la llegada del verano y subsecuentemente la elevación de la temperatura de las aguas del mar, propician una inusual abundancia que los pescadores de Huanchaco conocen como "El Tiempo de Abundancia." En este contexto, los ocasionales fenómenos del Niño son vistos por los pescadores locales como un exabrupto de un fenómeno anual en el cual, como ellos indican "... hay que ajustarse los pantalones..." pero que "... siempre hay pescao, otros pescaos y otros cangrejos, pero siempre hay..." También enfatizan que "... aunque hay días caóticos de inundaciones y hambrunas pa' los pájaros, pescaos, lobos y a veces nosotros, así es... es el ciclo natural." Cuando se les pregunto si es que es posible pedir a la Virgen que aleje las aguas tibias para alejar el fenómeno, estos rápidamente indicaron: “... nunca... eso sería imposible, y después, al pescao le da el frio y ya no entra a la bahía... en invierno hay mucho sufrimiento por el frio... no, el tibiaje y el calor nunca se pide que se aleje... es pecado..." En efecto, durante la temporada de verano, el debilitamiento de los vientos alisios, las corrientes y los levantamientos de aguas (upwellings) disminuyen al punto que favorecen el ingreso de aguas más tibias las cuales propician la llegada de especies como la anchoveta y detrás de ellas otras más grandes que son apreciadas por los pescadores (Fiedler et al. 1943; Schweigger 1947). Del mismo modo, otras especies marinas como los tollos y las rayas (elasmobranquios) se aproximan a las playas para desovar o dar a luz, por lo que se convierten en presa fácil de los pescadores. Por otro lado, las temperaturas propician la proliferación de variadas especies de moluscos las que junto con las constantes mareas bajas diurnas que se dan en el verano, permiten a las mariscadoras recolectar una serie de productos en las orillas. Finalmente, aunque ya no se ve debido a la masiva presencia del hombre en la zona, los pescadores refieren que en el pasado, especialmente en los meses de enero y febrero, los lobos marinos varaban en las playas para aparearse o criar sus cachorros, siendo también presa fácil de los pescadores quienes aprecian mucho su carne. Todos estos datos resumidos, pues son materia de un estudio más detallado (Prieto ms.) indican que el verano es una tem- porada de abundancia y plenitud productiva. Si tuviéramos que proponer una temporada en la que se celebraba en tiempos prehispánicos a la divinidad femenina del mar, el autor de este manuscrito contemplaría sin dudar que se dio en los meses de verano.

En este contexto llama la atención que la fiesta patronal anual de la Virgen del Socorro se celebre el 2 febrero, el mes más característico y representativo del verano en la costa norte del Perú. Es muy posible que los españoles advirtieran rápidamente que los pescadores realizaban festivales en honor a sus divinidades en el verano y por ello escogieron una advocación de la Virgen cuya fiesta se celebre en esos meses. Por ello es posible que la fiesta anual de la Virgen del Socorro cada 2 de febrero, evoque los antiguos festivales en honor a las divinidades prehispánicas femeninas del mar.

\section{La Romería Anual de la Virgen al “Cerro Chico” en Huanchaco}

De acuerdo a la leyenda narrada por don Mercedes, cuando la Virgen desembarca en Huanchaco, se le construye una ramada cerca de la playa donde se celebraba la misa y donde se efectuaba el adoctrinamiento de los nativos. Sin embargo la imagen de la Virgen comenzó repentinamente a desaparecer de esta ramada, desconociendo los pobladores su ubicación. La leyenda cuenta que unos mercaderes que iban hacia el valle de Chicama vieron a una señora y su hijo en un cerrito o promontorio rocoso que se encuentra aproximadamente a 2 kilómetros al noreste del pueblo de Huanchaco. Cuando los huanchaqueros llegaron, notaron con asombro que se trataba de la imagen de la Virgen recientemente llegada. Este promontorio es hoy conocido como "Cerro Chico" o "El Cerrito de la Virgen" dado el suceso que hemos indicado. Cabe destacar que este promontorio rocoso es un referente geográfico en las planicies desérticas al norte de Huanchaco (destacando su altura y color blanco) y cerca del mismo existe un asentamiento Chimú tardío, mientras que en las faldas mismas del promontorio se ubicó un cementerio de la misma cultura el cual ha sido 
intensamente saqueado desde la década del 40. En otra ocasión (Prieto 2009) hemos enfatizado también el rol que tuvo este promontorio en la organización y control de los campos y sistema de irrigación estatales Chimú ubicados en los alrededores del cerrito.

Cuando la imagen de la Virgen desapareció por más de dos veces y aparecía constantemente en dicho promontorio, los pobladores y el sacerdote de Huanchaco advirtieron que la Virgen quería tener su santuario en el la parte alta del pueblo y no cerca de la playa. Lo que resulta interesante es que su santuario no se construyó en el cerrito, sino en una loma inmediata al este del pueblo (Fig. 3).

Debido a las apariciones de la Virgen en el promontorio rocoso, cada año durante su celebración anual, una imagen alterna (conocida como La Interina) de la Virgen es conducida en romería al cerrito desde tempranas horas de la mañana y regresa cuando el sol comienza a ponerse (Prieto 2009: 281). Todo el pueblo aprovecha la ocasión para trasladarse hacia dicho punto y almuerzan en la zona organizados por sus grupos familiares. Cada grupo toma un lugar en el cerrito y arman pequeñas ramadas donde disponen la comida (Fig. 4). El cerrito tiene unas perforaciones naturales las cuales se llenan en esa época de agua debido a las ocasionales lluvias de verano en Huanchaco. Los pobladores creen que dicha agua es bendita y antiguamente la llevaban en recipientes a sus casas.

En otra ocasión hemos enfatizado la relación que existe entre el verano, la romería al promontorio rocoso y la llegada de las aguas por el cauce del rio seco al sur del pueblo y que pasa cerca al Cerrito de la Virgen (Prieto 2009). Más interesante aún es que de acuerdo a los viejos pescadores de Huanchaco, el tiempo de verano también era propicio para sembrar la tierra. Don Mercedes nos narraba que el pescador de Huanchaco se daba abasto para dos actividades: pescaba y en tiempos de verano también de dedicaba a la agricultura estacional. Cuando le preguntamos con qué agua sembraban, dijo que con el "Agua de Dios que viene a dar aquí a la mar." Hasta antes del Fenómeno El Niño de 1998, el cauce del río Seco de Huanchaco traía anualmente agua

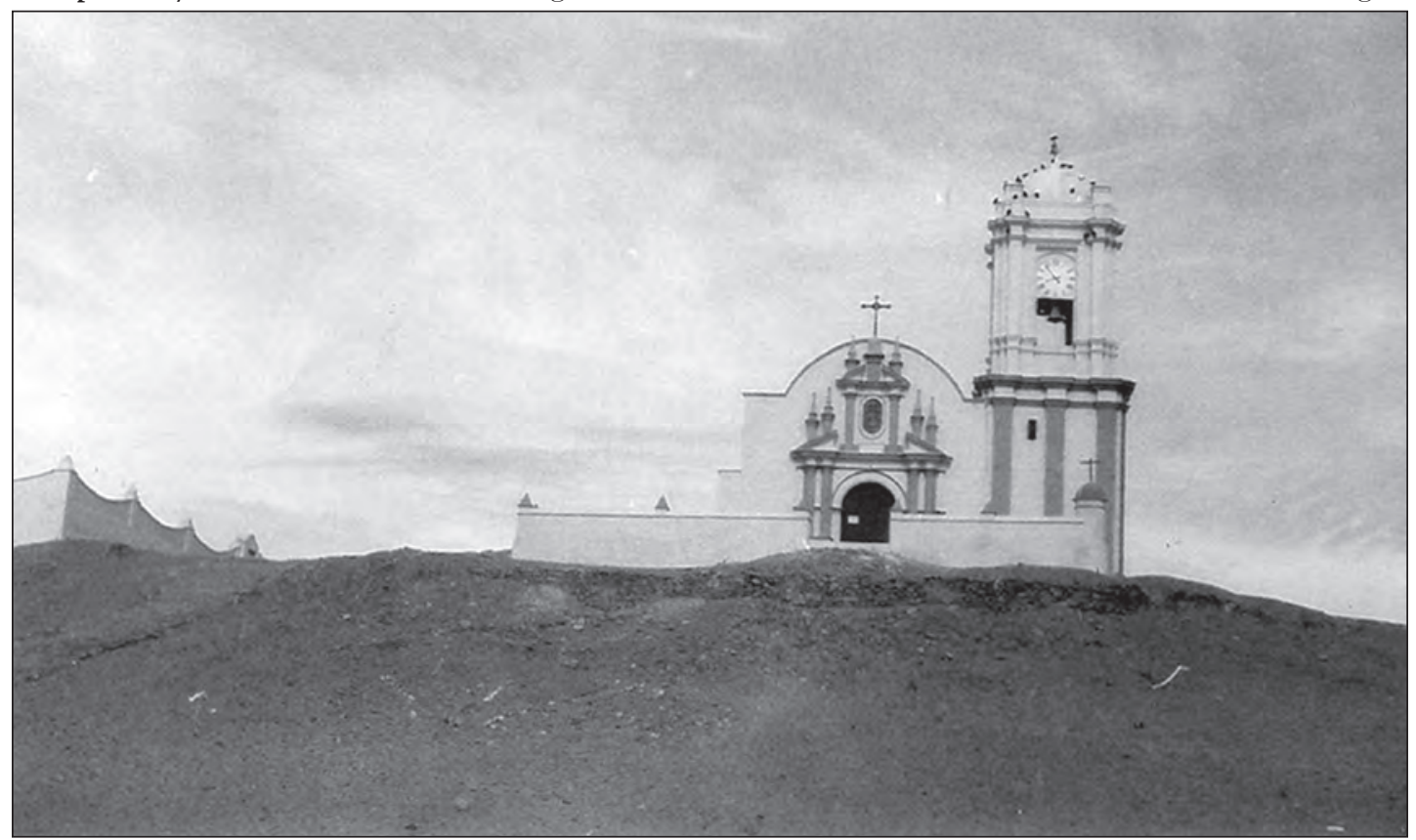

Figura 3. El Santuario de la Virgen Candelaria del Socorro de Huanchaco. Fotografía tomada en la década de 1950. (Cortesía de Margarita Venegas). 


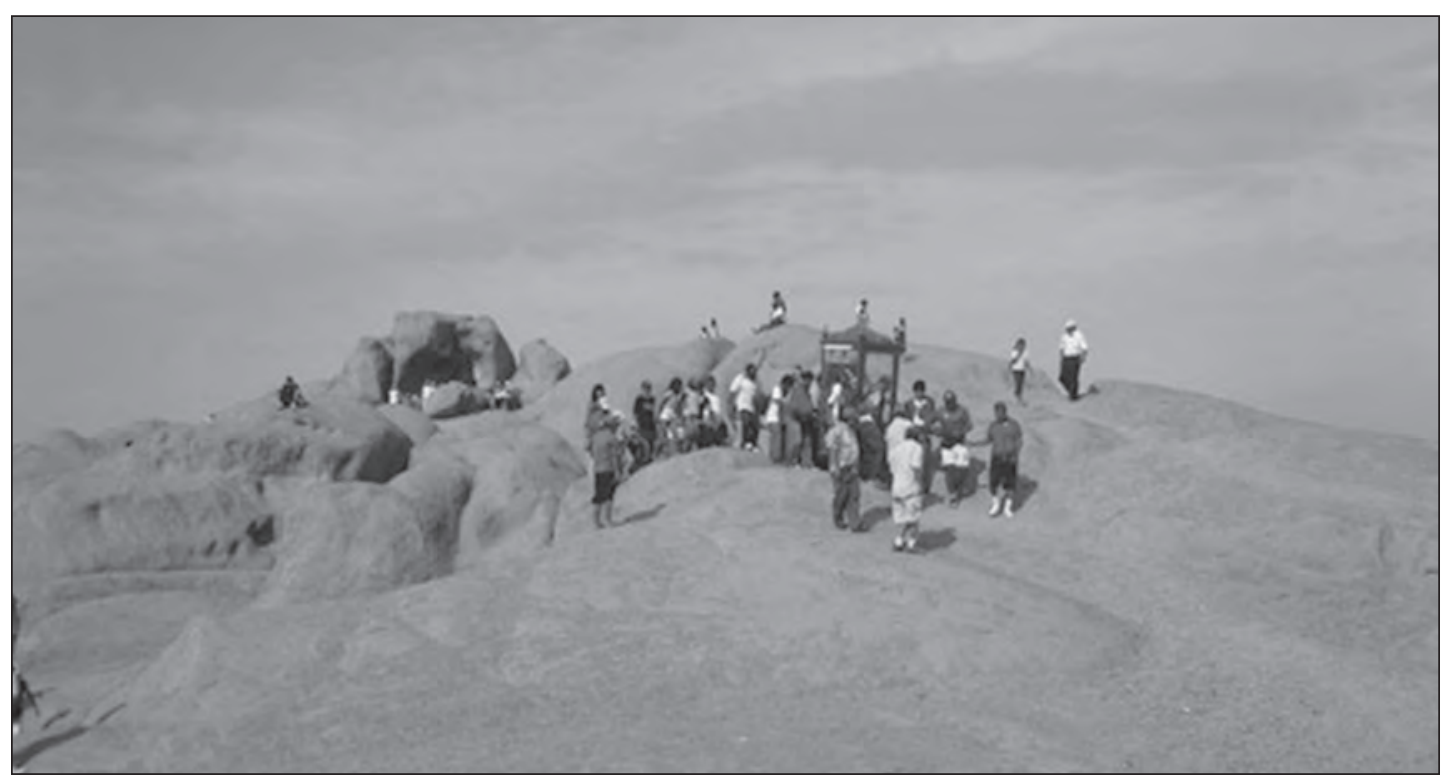

Figura 4. Romeria anual de la Virgen del Socorro al Cerro Chico o Cerrito de la Virgen.

hacia fines de enero, durante todo el mes de febrero y ocasionalmente en marzo. Esta agua era aprovechada por los pescadores para sembrar en los terrenos eriazos que se encontraban en la parte posterior del pueblo, en la zona de Valdivia y Pampas de Alejandro que hoy están casi completamente urbanizadas. En dichos meses sembraban lagenarias (calabazas), sandias, frijoles, camotes, entre otros productos.

Es muy probable que la romería al promontorio guarde alguna relación con alguna ceremonia que en el pasado se realizaba allí para propiciar la llegada de las aguas. Los cerros costeños, son vistos por los pobladores locales como seres masculinos, como los retenedores de la humedad y las nubes, así como la casa de los ancestros (León Barandiarán 1938). Es posible que al menos desde el periodo Chimú, los pobladores de Huanchaco hayan reconocido a dicho promontorio como una huaca o lugar sagrado donde enterraron a sus muertos. Por ello, las celebraciones prehispánicas pudieron estar relacionadas a la llegada del agua para propiciar la agricultura en la zona. Los vastos campos de cultivo prehispánicos en las inmediaciones son una clara evidencia de ello (Ortloff 1981). Por otro lado la visita simbólica de una divinidad femenina como la imagen alterna de la Virgen
Candelaria del Socorro al cerrito, puede representar la unión del elemento masculino (cerro) y el femenino (Virgen) para propiciar la llegada de las aguas del río por medio de la lluvia en la sierra. Por lo tanto, la romería anual de la Virgen a ese sector guarda relación con antiguas prácticas locales que buscaban propiciar la fertilidad de la tierra a través del agua que llegaba estacionalmente por los cauces secos, producto de las lluvias en la sierra.

Existe además otra razón por la cual los pescadores esperan tanto la llegada de esas aguas o como Don Mercedes las denominó "El Agua de Dios". De acuerdo a sus creencias, el agua de dicho cauce propiciaba la proliferación de especies marinas en las playas rocosas y con ello una mayor abundancia de recursos en las playas. Varios biólogos pesqueros han enfatizado también que codiciadas especies de peces como corvinas, robalos y cojinovas, frecuentan las desembocaduras de los ríos para alimentarse del detritus que generan las aguas dulces y también debido a la rica biodiversidad de las playas cerca de estas zonas debido a la regulación de la salinidad ocasionada por la presencia de agua dulce (Schweigger 1943: 174). Por lo tanto, existe una clara relación también con la intención que las aguas dulces del río lleguen a la costa pues propiciaban 
una mayor diversidad marina y por lo tanto mejoraban la pesca.

En otra ocasión hemos argumentado que el mito de la costa central de Urpay Huachac (Rostworowski 2004) podría haber simbolizado la mágica unión de un elemento masculino (el río representado por Cuniraya) y un elemento femenino (el mar representado por Urpay Huachac) que daba como resultado la presencia de peces en el mar (entre otras especies) y por lo tanto la abundancia marina (Prieto 2009: 282). Es posible entonces que a nivel pan-costeño la llegada de un mayor caudal en los ríos costeños durante los meses de verano haya sido apreciada como la fecundación de estos hacia el mar, propiciando la abundancia de especies marinas en sus alrededores y en general durante la temporada de verano.

La fiesta anual de la Virgen Candelaria de Huanchaco guarda entonces dos trasfondos articulados en torno a la fertilidad. Por un lado es una imagen que vela desde su santuario por los pescadores y que propicia la buena pesca, mientras que al mismo tiempo, su visita anual al promontorio rocoso promueve la llegada estacional de las aguas dulces por los cauces secos para propiciar el cultivo estacional de la tierra y atraer una mayor biodiversidad marina en las inmediaciones de su desembocadura. Si nuestras interpretaciones son correctas, entonces se puede concluir que dicha fiesta está íntimamente ligada a la fertilidad del mar y la tierra y al bienestar de la comunidad de pescadores garantizando su acceso a fuentes de alimento. Es obvio que debió haber otros significados y detalles pero por el momento solo nos atrevemos a enmarcar las líneas generales de esta divinidad y su festival principal, hoy representada por el icono católico de la Virgen María y su fiesta patronal.

\section{LA FIESTA DEL HUANCHAQUITO O BAJADAS QUiNQUENALES DE LA VIRGEN CANDELARIA DEL SOCORRO DE HUANCHACO}

Esta fiesta es la única celebración católica cíclica de la costa norte del Peru (Schaedel 1989: 166). Fue instaurada en 1681 por el Cabildo Eclesiástico para celebrar las novenas en honor a la Purísima Concepción de la Virgen María en la ciudad de Trujillo. El nombre de "Fiesta del Huanchaquito" fue dado por el acervo popular dado que cada 5 años, cuando la imagen de la Virgen Candelaria de Huanchaco visitaba la ciudad de Trujillo, los pobladores huanchaqueros se establecían temporalmente en las afueras de la ciudad, formando un pequeño pueblo que los trujillanos conocían como "Huanchaquito." Este emplazamiento temporal era una suerte de feria donde se podía degustar platillos típicos de Huanchaco los cuales eran muy apreciados por los ciudadanos. Esta feria y emplazamiento temporal duraba hasta que terminaba las solemnidades que la imagen presidía y luego retornaba acompañando de regreso la procesión hasta Huanchaco. Este es un evento muy esperado por los huanchaqueros y es relevante mencionar que los pobladores de pueblo miden su edad de acuerdo al número de bajadas a las que han asistido. Todos los pobladores participan de una u otra manera en la festividad, sea como cargadores, danzantes (danza de los Diablos de Huanchaco) o cantantes (Las Pallas o Chinas como se conocía anteriormente). Al mismo tiempo participan como acompañantes, y en las labores que implica la organización de la festividad. Cabe indicar que la fiesta es presidida por la imagen antigua de la Virgen Candelaria del Socorro de Huanchaco a la cual llaman "La Patrona," mientras que en las fiestas anuales y en las romerías al Cerro Chico, utilizan a "La Interina." El hecho de descender de su altar a "La Patrona" cobra especial significado y por eso la fiesta es tan esperada y estimada entre los pobladores de Huanchaco.

\section{Contexto histórico de la Fiesta del Huanchaquito}

El primer registro conocido de la visita de la Virgen Candelaria del Socorro de Huanchaco a Trujillo data de 1674 . Se sabe por las actas del Cabildo Eclesiástico que era una tradición llevar en peregrinación y procesión diferentes imágenes entre los templos de Trujillo. También era costumbre en tiempos virreinales llevar las imágenes de los santos de los pueblos circundantes a la ciudad e incluso visitaban los campos o ca- 
nales de irrigación para propiciar su buen desempeño. En ese sentido, el Señor de Huamán ${ }^{4}$ (patrón del pueblo de Huamán) era muy popular para dichos oficios. De acuerdo a los libros del cabildo eclesiástico de Trujillo consta que la ciudad se consagró a San Esteban y Santiago contra las pestes y demás calamidades públicas; a San Francisco Solano contra los terremotos y temblores; a San Juan Bautista contra la esterilidad de los campos y a San Valentín se le denominó patrono de la ciudad. Asimismo, la tradición de traer santos a la ciudad o hacer peregrinaciones en los alrededores era tan antigua como su fundación. Por ejemplo, el 18 de setiembre de 1608, debido a la gran escases de agua que sufrían los campos de la ciudad de Trujillo se acordó que se haga una procesión que salga de la Iglesia Mayor y después vaya al monasterio de Nuestra Señora de las Mercedes. En 1663 y 1664 las imágenes de la Virgen del Rosario y el Señor de Huamán fueron llevados en santa procesión desde sus templos hacia el convento de Santa Clara la Real y a la Iglesia Mayor de la ciudad respectivamente para aplacar plagas y evitar terremotos (Imprenta Diocesana 1931).

Hacia la segunda mitad del siglo XVII, el ambiente religioso estuvo muy exacerbado debido a la canonización de Santa Rosa de Lima la cual fue la primera santa peruana y de todas las Américas (Flores Araoz et al. 1995; Del Busto 2006). Las celebraciones que se hicieron en todo el virreinato generaron una serie de manifestaciones de fe y sensibilidad espiritual que caló muy hondo en la memoria colectiva del pueblo (Fernández de Córdova 1818). Por otro lado, el 22 de noviembre de 1674, la reina española María Ana de Austria, instituyó a la Virgen Candelaria de Medellín, Colombia como patrona de la ciudad. Es posible entonces, que desde

4 Adviértase que en la versión de la leyenda de Don Mercedes Díaz, la imagen del Señor de Huamán llegó junto con la imagen de la Virgen Candelaria de Huanchaco. El 2008 registramos una versión similar en el pueblo de Huamán en la cual se refería a la llegada del Señor de Huamán con "otros santos" y la cual fue hallada flotando en el mar por pescadores locales (Prieto 2008). Cabe anotar que los huanchaqueros son también muy devotos del Señor de Huamán y tienen lazos de parentesco con los pobladores de ese pueblo.
España, se haya pedido extender y reforzar el culto a esta advocación de la Virgen, dado que ese mismo año, la Virgen Candelaria del Socorro de Huanchaco es traída a Trujillo.

De acuerdo al acta de instauración, la ciudad de Trujillo recibió anualmente entre 1674 y 1681 a la imagen de la Virgen Candelaria del Socorro de Huanchaco para las tradicionales celebraciones de la fiesta de la Purísima Concepción cada 8 de diciembre. Anteriormente dicha fiesta era presidida por la imagen de la Virgen del Rosario que se custodia hasta el día de hoy en el templo de Santo Domingo de la ciudad de Trujillo. Por aquellos años, el Licenciado y Dean de la Catedral de Trujillo, Antonio de Saavedra y Leiba, ejercía el cargo de máximo representante de la Iglesia en la ciudad, dado que el obispo de turno, no llegaba aún a tomar cargo de su posición. Fue entonces Saavedra y Leiba quien decide instaurar una tradición religiosa y de esta manera traer no anualmente, pero cada cinco años, a la Virgen para que presida las fiestas de la Purísima Concepción.

Aunque el acta de instauración señala que la ciudad de Trujillo se encontraba en una "grave necesidad y trabajo" no existen documentos de la época que refieran a plagas o terremotos en la ciudad ese año (Castañeda ms). Juan Castañeda cree que la "grave necesidad y trabajo" se debió a un caso de posesión demoniaca en el convento de Santa Clara La Real de Trujillo (Blanco 1994; Lemlij 1994). De acuerdo a documentación etnohistórica, dos monjas fueron víctimas del demonio, lo cual altero los ánimos en la ciudad una vez que se hizo de conocimiento público. Castañeda, basado en las fechas, cree que la imagen de la Virgen Candelaria del Socorro es traída a la ciudad de Trujillo para "socorrer" esa necesidad (Castañeda ms). Por esa razón, una de las paradas de la procesión es en dicho convento, donde pernocta por algunos días y donde es además cambiada de su traje de "viajera" o "huanchaquerita" por el de patrona y reina de la ciudad.

Es muy probable entonces que una mezcla de varios sucesos incluyendo el contexto religioso (canonización de Santa Rosa de Lima, entronización de la Candelaria de Medellín) y político (acrecentar la fe y la lealtad a la corona 
por medio de fiestas y celebraciones religiosas) de la época hayan impulsado la iniciativa de establecer la peregrinación religiosa de la Bajada Quinquenal de la Virgen Candelaria del Socorro de Huanchaco a la ciudad de Trujillo.

\section{El fundador de la fiesta del Huanchaquito}

Don Antonio de Saavedra y Leiba nació en Lima en 1636 y fue hijo del Oidor D. Fernando de Saavedra y Da. Catalina de Aliaga y Bermeo. Cursó estudios en el Seminario Conciliar de Santo Toribio y posteriormente en la Universidad de San Marcos graduándose como Bachiller en Sagrada Teología. Al año siguiente ocupó una vacante en el cabildo catedralicio de Trujillo en calidad de Racionero. En 1670 fue promovido a Canónigo de merced, luego a Arcediano (1674) y Deán (1675). Desempeñó asimismo el cargo de Comisario del Santo Oficio y tuvo que gobernar la diócesis en sede vacancia desde la muerte del Obispo Francisco de Borja (1669), hasta la llegada de Pedro Díaz de Cienfuegos (1696). En 1700 por encargo del Virrey Conde de la Monclova fue nombrado Juez de Aguas y en ejercicio de este cargo redactó un reglamento de aguas que ha tenido vigencia hasta el siglo pasado. Ya anciano renunció al deanato y se retiró a vivir al pueblo de Mansiche. Promovió el culto a la Virgen del Socorro en Huanchaco, en su testamento expresó la voluntad de que se fundara una obra pía para que

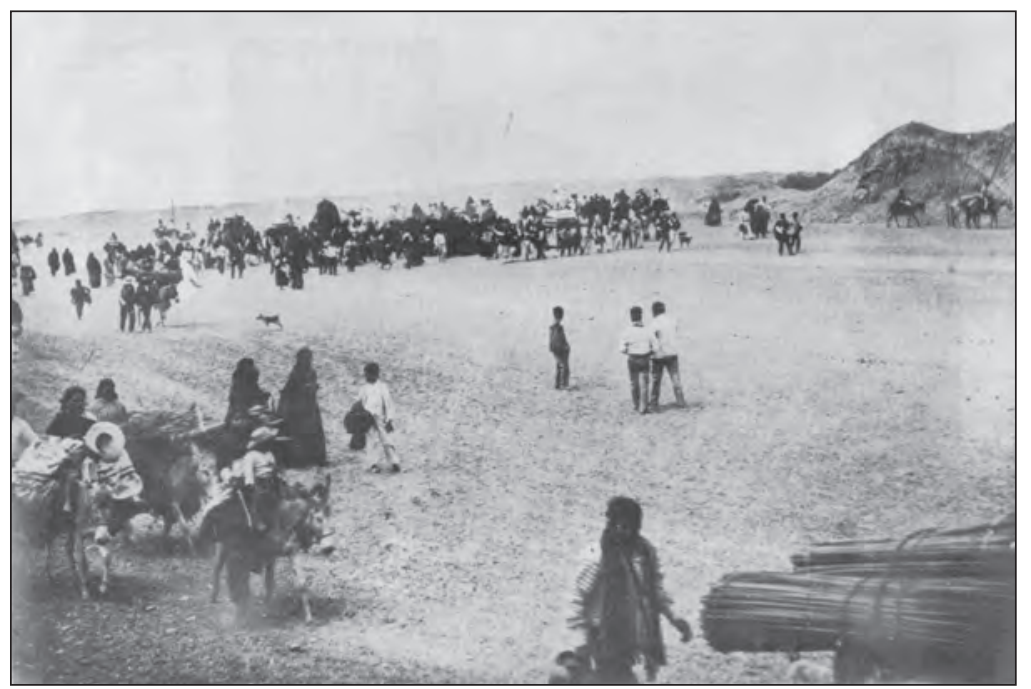

de lo que redituase de pudiera financiar la venida de dicha imagen a la ciudad de Trujillo cada cinco años. De su peculio además erigió la iglesia de San José, para que sirviera como pascana en peregrinación que hiciera Nuestra Señora a la ciudad. Realizó múltiples obras para embellecer los templos trujillanos. Por ejemplo, mando hacer los grandes lienzos que adornan las paredes laterales de la Catedral de Trujillo. También, dado su especial devoción por la Virgen del Rosario, reconstruyó el altar que dicha imagen tiene dedicado en la iglesia de Santo Domingo. De su gestión, también mandó a embellecer la iglesia de Angasmarca, la cual es un referente actual del barroco mestizo de la sierra norte del Perú. Falleció en olor a santidad en 1707, y su cuerpo incorrupto está sepultado en la iglesia de Huanchaco, edificio que asimismo reconstruyó (Castañeda ms.)

\section{Descripción de la fiesta del Huanchaquito}

La fiesta del Huanchaquito ha cambiado a lo largo de su historia en la estructura, el significado y su recorrido. Sin embargo, algo que se ha mantenido desde el comienzo, es respetar los periodos de 5 años (o quinquenios) entre cada celebración. La documentación gráfica más antigua que se tiene de la Fiesta del Huanchaquito se la debemos a la cámara de Heinrich Bruning (Schaedel 1989: 178) (Fig. 5). De acuerdo a las descripciones más antiguas, la imagen salía de su santuario en Huanchaco e iba directamente a la $\mathrm{Ca}$ pilla de San José, ubicada a mitad del camino de carretas, nombre que se le daba antes a la actual autopista que une Trujillo y Huanchaco (Fig. 6). Allí era recibida por la imagen de San José, quien la escoltaba hasta la misma capilla. Allí se descansaba por un día y a la

Figura 5. Fotografia captada por Heinrich Bruning en 1895 en las inmediaciones de Chan Chan, camino a Trujillo. 


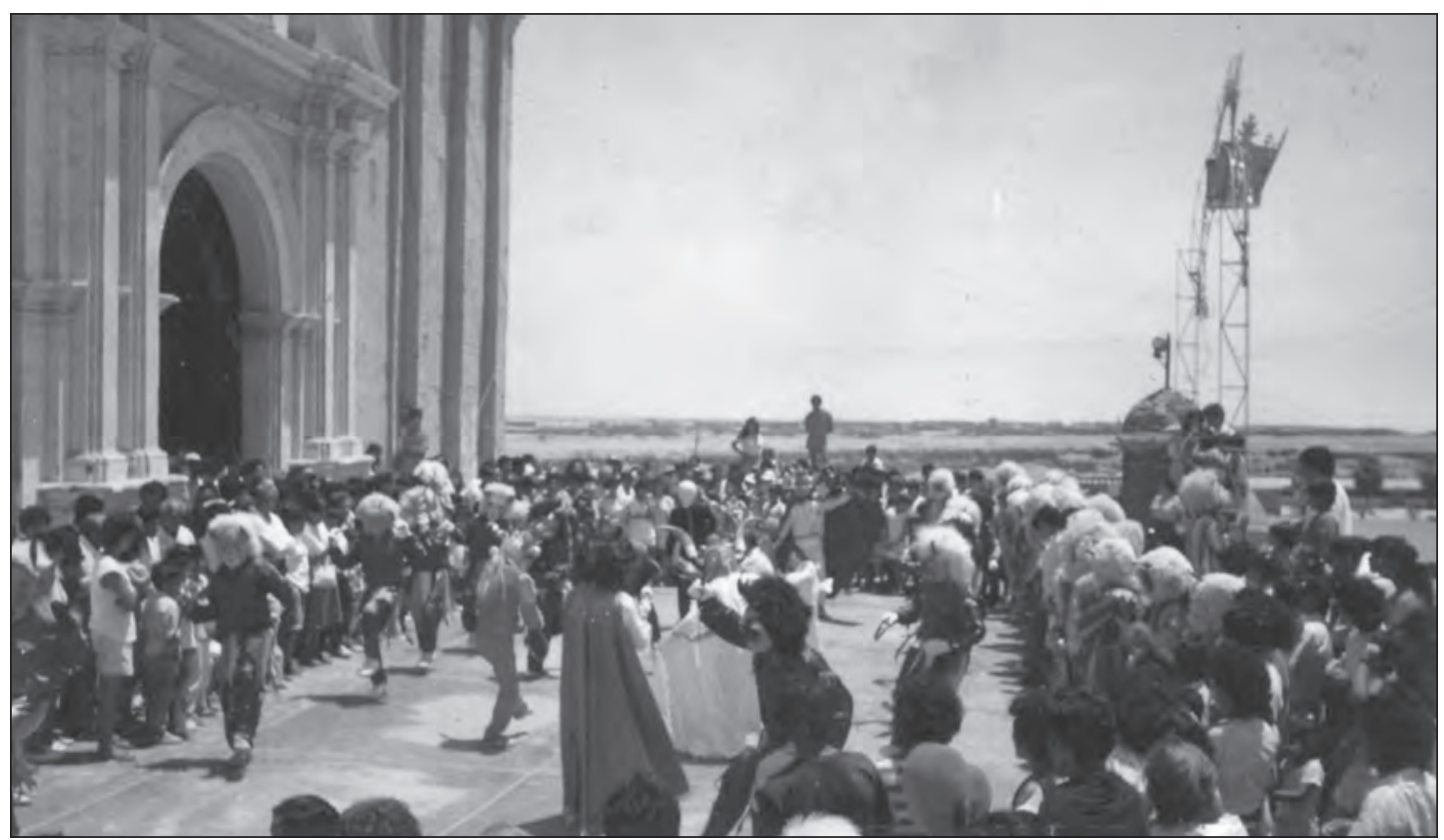

Figura 6. Despedida de la imagen en el atrio de su Santuario.

Fiesta del Huanchaquito de 1985 (Cortesía de Jorge Luján).

mañana siguiente la pareja de imágenes salían rumbo a la entrada de Trujillo, previa parada en Mansiche. La imagen de San José entonces se quedaba allí hasta el retorno de la imagen de la Virgen Candelaria del Socorro. Desde Mansiche, la Virgen avanzaba triunfalmente hasta la muralla de Trujillo por la entonces alameda de Mansiche (hoy Av. Mansiche) y allí, en el portal del mismo nombre, era recibida por el pleno del Cabildo Eclesiástico y Civil, así como por otras imágenes de culto de las cuales no se tiene registro. Luego del homenaje, la procesión solemne se dirigía hacia la iglesia de Santa Ana, donde se hacían algunas plegarias. Posteriormente se pasaba al convento de los Franciscanos donde pernoctaba algunos días. Luego era llevada al convento de Santa Clara la Real y allí era homenajeada por las monjas de dicho convento. Finalmente la imagen entraba en procesión solemne las vísperas de la fiesta de la purísima concepción a la Plaza Mayor de la ciudad, donde se instalaba en la Catedral. El día central, es decir el 8 de diciembre, la imagen recorría la Plaza y algunas calles principales (Fig. 7). El 15 de diciembre regresaba a Santa Clara la Real donde se le vestía apropiadamente para su re- torno, guardándose sus joyas y aderezos para el próximo quinquenio. En el siglo XVIII comenzó a visitar el entonces flamante convento de las monjas carmelitas de Santa Teresa donde le cantaban y adoraban. Posteriormente regresaba a Huanchaco, siendo acompañada por la imagen de San José, llegando en las vísperas del 24 de Diciembre para celebrar en su pueblo el nacimiento de Dios. No se sabe a ciencia cierta que danzas acompañaban a la Virgen. Solo se conoce que se pagaba a unos niños para que canten junto a la imagen. Por otro lado, los documentos mencionan las ferias, corridas de toros y espectáculos de fuegos artificiales que acompañaban la festividad, lo cual ponía una nota alegre y de integración entre los ciudadanos, las familias de los pescadores huanchaqueros y los demás pueblos de las inmediaciones.

Hoy en día, el recorrido se ha complejizado debido a los modernos centros poblados que existen entre Huanchaco y Trujillo. Así mismo, múltiples instituciones piden la visita de la santa imagen, por lo que los recorridos dentro de la ciudad de Trujillo varían de quinquenio en quinquenio. Por otro lado se han adicionado 


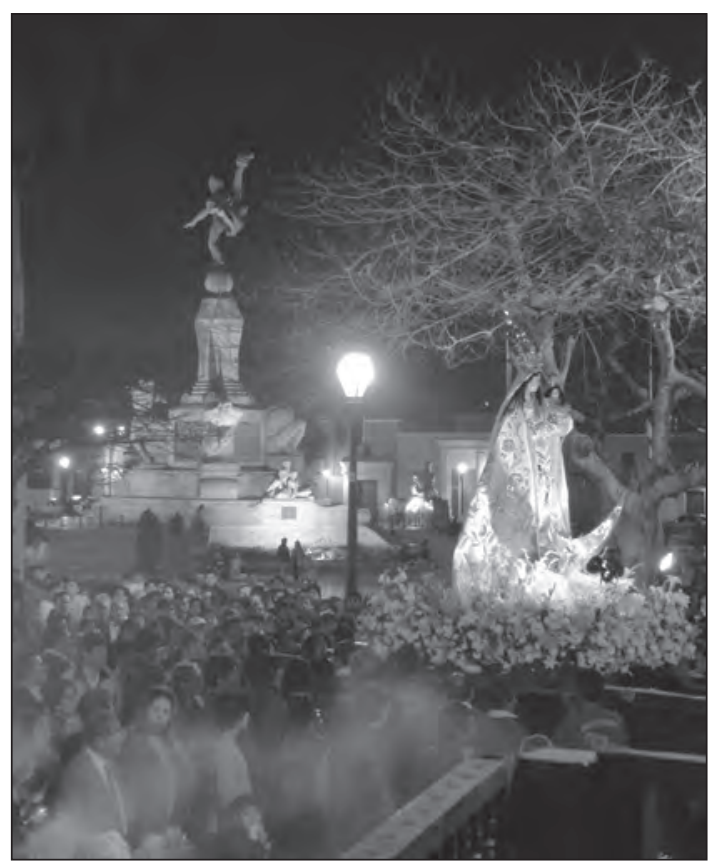

Figura 7. Procesión del dia central de la Fiesta Quinquenal (8 de diciembre) en la ciudad de Trujillo.

danzas y agrupaciones que dan colorido y alegría a las procesiones.

\section{El significado de la fiesta del Huanchaquito}

El objetivo de la Fiesta del Huanchaquito, es la visita quinquenal de la imagen de la Virgen Candelaria del Socorro de Huanchaco a la ciudad de Trujillo. De acuerdo a las descripciones más tempranas de la fiesta, la primera parada de la imagen o "pascana" se daba en la Capilla de San José, presidida por la imagen del mismo santo. Al parecer el recorrido en sus inicios pretendía adoctrinar a los pobladores de Huanchaco en los misterios de la fe católica, mientras que de cara a los ciudadanos trujillanos, se trataba de enfatizar la pureza de la Virgen y sus sagrados misterios. Por ello, es posible que el encuentro de las dos imágenes en la capilla (La Virgen y San José), haya representado los desposorios de la sagrada pareja. Esto se puede enfatizar en el hecho que en la antigua litera de madera que se usaba en el recorrido, hay un lienzo que grafica los desposorios de estos personajes (Fig. 8). A la mañana siguiente ambas imágenes se desplazaban hacia Mansiche, donde eran recibidas por la población. Allí se quedaba la imagen de San José y la Virgen proseguía sola su recorrido hasta el portal de Mansiche. Allí era recibida por el pleno del Cabildo Eclesiástico y Civil, donde se le entregaban las llaves de la ciudad. Seguidamente la imagen iba a la Iglesia de Santa Ana, la cual funciono como Iglesia Mayor de la ciudad por mucho tiempo. Allí, se evocaba la figura de la madre de María y su rol para formar a la futura madre de Dios. Coincidentemente, otro lienzo de la antigua litera de la Virgen, grafica a Santa Ana enseñando las sagradas escrituras a una joven María (Fig. 9). Luego la imagen de la Virgen Candelaria del Socorro de Huanchaco se dirigía al monasterio de San Francisco, donde le eran cantadas misas solemnes para luego ingresar y descansar por unos días en el Convento de Santa Clara la Real. Allí, era adorada y preparada por sus monjas para las vísperas del Novenario de Nuestra Señora. Es interesante que la imagen sea vestida con sus mejores vestidos y joyas para los días centrales de la celebración, mientras que en el resto de la festividad, viste sencillos trajes que emulan los vestidos típicos de las mujeres huanchaqueras. Tras las celebraciones centrales y terminada su visita en Trujillo, regresaba a Huanchaco donde era acompañada desde Mansiche hasta el puerto por la imagen de San José el mismo 24 de diciembre, lo cual es probable que haya representado la búsqueda de alojamiento por parte de la sagrada pareja para dar a luz a Jesús. Una vez en Huanchaco es recibida con una fiesta a la entrada del pueblo y luego se le conduce a su santuario donde preside la misa del Gallo para recibir la noche buena.

Hoy en día el recorrido ha variado mucho, existiendo múltiples "pascanas" o paradas entre Huanchaco y Trujillo. Quizá una de las pascanas que tiene una gran antigüedad pero que nunca fue mencionada es la que los huanchaqueros hacían en el paraje denominado "El Chilco" (a la altura del actual aeropuerto de la ciudad). El Chilco (Baccharis lanceolata) es un arbusto local que crece en las pampas eriazas al sur de Huanchaco y que hoy está casi extinto. La parada o pascana que frecuentaba la imagen era un gran arbusto de Chilco el cual también era usado en el pasado como seña por los pescadores para ubicar la distancia y zona en la que se 


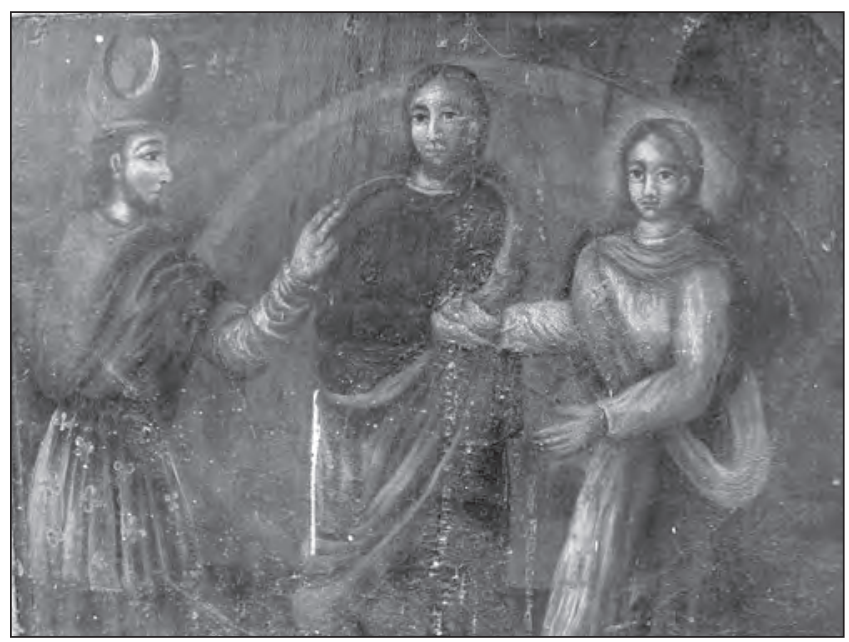

Figura 8. El oleo de los Desposorios de la Virgen y San José en la litera antigua.

encontraban pescando. En el Chilco se hacían oraciones y luego se procedía a continuar con la procesión. El origen y significado de esta pascana se ha perdido para siempre, pero está definitivamente asociada a las prácticas paganas de los pobladores de Huanchaco, quienes fusionaron sus antiguas creencias con las que trajeron los hispanos en el siglo XVI.

El significado de esta fiesta tiene diversos ángulos. Por un lado, indica la devoción mariana de la ciudad de Trujillo desde el periodo virreinal. Por otro lado inculcó la religiosidad y espiritualidad al pueblo de Huanchaco, quien inconscientemente se catequiza a través del significado codificado de su recorrido. Al mismo tiempo, emula puntos o "pascanas" culturalmente significativas en la historia de Huanchaco y Trujillo: El paraje del Chilco, los palacios de Chan Chan, la antigua Iglesia Mayor de la Ciudad (Santa Ana) el monasterio de San Francisco, el muy conocido convento de Santa Clara la Real (el más grande en su tiempo de todo el virreinato peruano) y por supuesto la Catedral.

\section{Las Danzas de la Fiesta del Huanchaquito}

Dado el espacio disponible, solo haremos un breve recuento de cada danza que es característica de esta festividad. Cabe indicar que Carmen

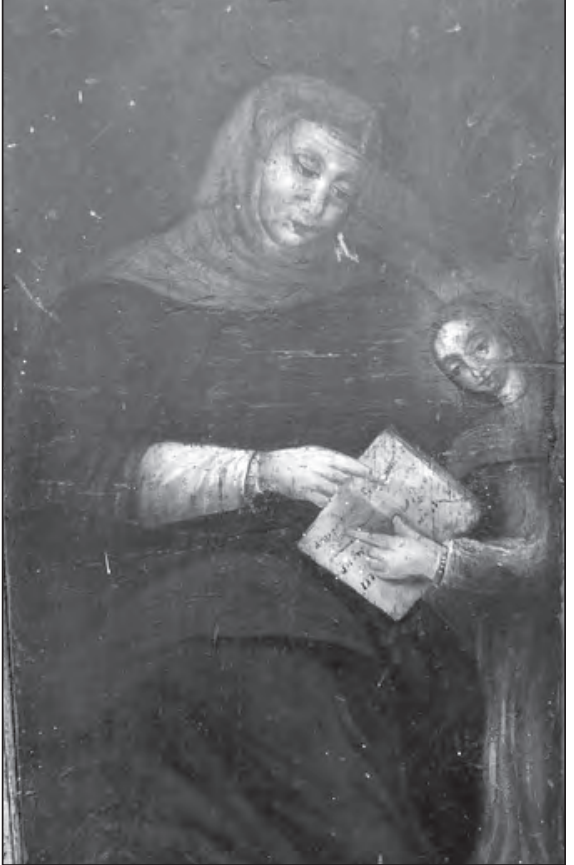

Figura 9. Oleo de Santa Ana enseñando las sagradas escrituras a la joven Virgen María.

García (2001) ha realizado una detallada descripción de estas danzas y otros aspectos de la fiesta. Del mismo modo se podrá encontrar otros detalles en un trabajo recientemente publicado por el profesor José Elías Minaya (Minaya 2008) y si se desea tener una excelente perspectiva endógena, se deberá revisar el trabajo publicado por Pedro Anhuamán (Anhuamán 2008: 179). Podemos indicar que hay dos tipos de danzas: las que son propiamente de la festividad (Las Pallas o Chinas y la Danza de los Diablos de Huanchaco) y las que son "invitadas" o "periféricas" como la Danza de los Indios de Santiago de Cao, los Diablos de Moche o los Negritos de Catamblá de Huanchaco.

\section{La Danza de los Diablos de Huanchaco}

Mucho se ha especulado sobre el origen de esta danza. En los últimos años, se ha venido argumentando que la danza graficada en las acuarelas del ilustrísimo arzobispo de Trujillo Baltazar Jaime Martínez de Compañón, es la evidencia más 
antigua de la danza de los Diablos de Huanchaco. A pesar que puede existir alguna conexión entre esta acuarela y la danza en discusión, el proceso es mucho más complejo de lo que parece. La danza graficada por Martínez Compañón es probable que representa una muy difundida en España y en América durante el virreinato: "La Danza de los Siete Pecados Capitales." En esta danza, cada diablo representaba a un personaje distinto, y se podría argumentar que era una suerte de coreografía individualizada (Fig. 10). Esta danza fue traída por los españoles al virreinato peruano y a donde llegó fue reestructurada y reinterpretada de acuerdo a las creencias y tradiciones de cada pueblo. Esta danza se volvió vital en el proceso de evangelización pues el problema del conocimiento y la aversión a los siete pecados capitales era una parte principal de las doctrinas católicas enseñadas a los indígenas

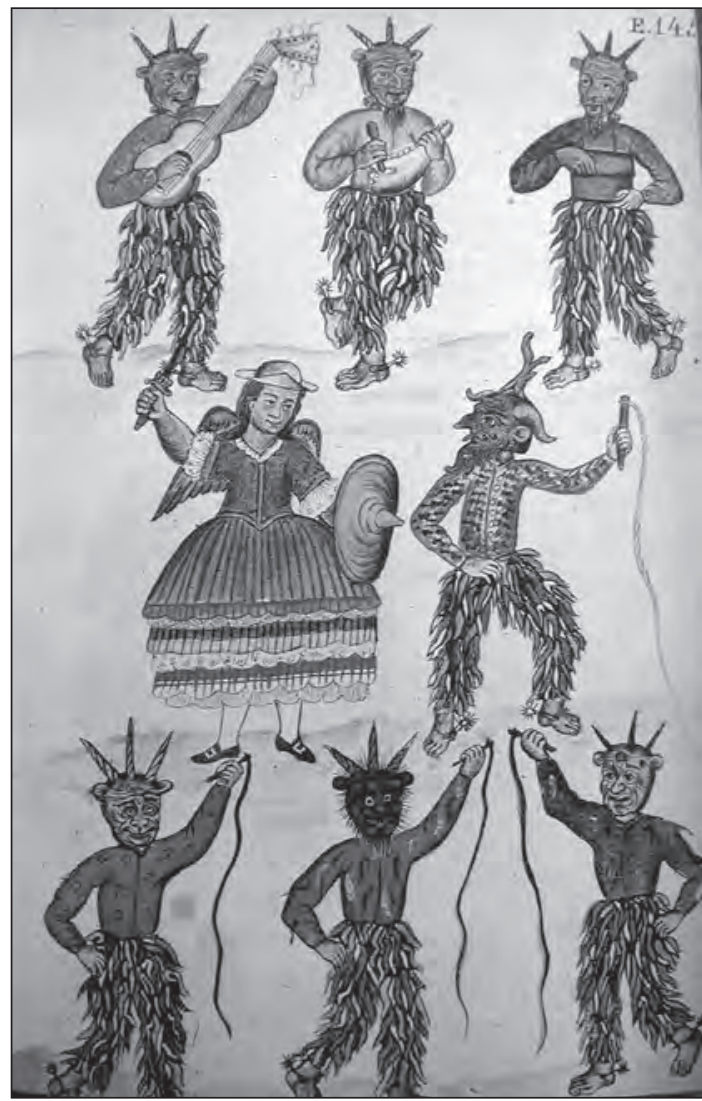

Figura 10. Danza de los Siete Pecados Capitales, ilustrada por el obispo Baltazar Martínez Compañón.
(Mendoza et al. 2002). Por lo tanto, tenía mucho interés de los misioneros durante el virreinato. Por ejemplo, en el pueblo de Juli (Puno) la danza dramatizaba los auto sacramentales dirigidos por los jesuitas (op. cit.).

En Huanchaco existió una danza llamada "Danza de los Sotas de Bastos" o simplemente la "Danza de Sota" la cual se bailaba en las festividades de la Virgen del Socorro. Ésta era acompañada por un bombo, clarinete, platillos y eventualmente un saxo. Estaba compuesta de seis personas y el disfraz era de dos colores: rojo y verde. En vez de un látigo, llevaban en la mano un bastón. Sin embargo los ritmos y los pasos eran muy similares a los que practican hoy los Diablos de Huanchaco. Es probable que la Danza de Sota, sea una reinterpretación y una reminiscencia de las danzas traídas por los españoles en el siglo XVI y que se fusionó como las danzas indígenas de los pobladores de Huanchaco. Lamentablemente, no existen fotografías o descripciones más detalladas de esta danza.

En 1937, Arturo Jiménez Borja redactó una pequeña pero muy importante descripción de la danza de los Diablos de Huanchaco. De acuerdo a sus descripciones, el cuerpo de baile era de 14 personas, de las cuales 12 eran del coro y 2 comandaban la danza como "capataces." El primero de los capataces danza adelante tratando de abrir espacio para los bailarines, mientras que el segundo danzaba entre las dos filas de danzantes corrigiendo los movimientos y acompasando el grupo. En medio del grupo se movían dos figuras un pequeño diablo y una mujer interpretada por un bailarín (Jiménez Borja 1937). Los vestidos eran de tres piezas: pantalón corto, blusa con falda cortada a picos y una pequeña esclavina. El tocado de la cabeza era un pellejo de carnero teñido de rojo y una máscara de rejilla de alambre con dos cuernos. Todo el disfraz estaba atiborrado de cascabeles que sonaban acompasados de acuerdo a los movimientos de los danzantes. Los capataces iban vestidos de mallas de color rojo muy ceñidas y junto con los demás, usaban un látigo rojo con el que juegan constantemente. Los músicos eran tres, dos de ellos tocaban las quijadas de burro y el tercero tocaba el cajón o la concertina (op. cit.) (Fig. 11). 


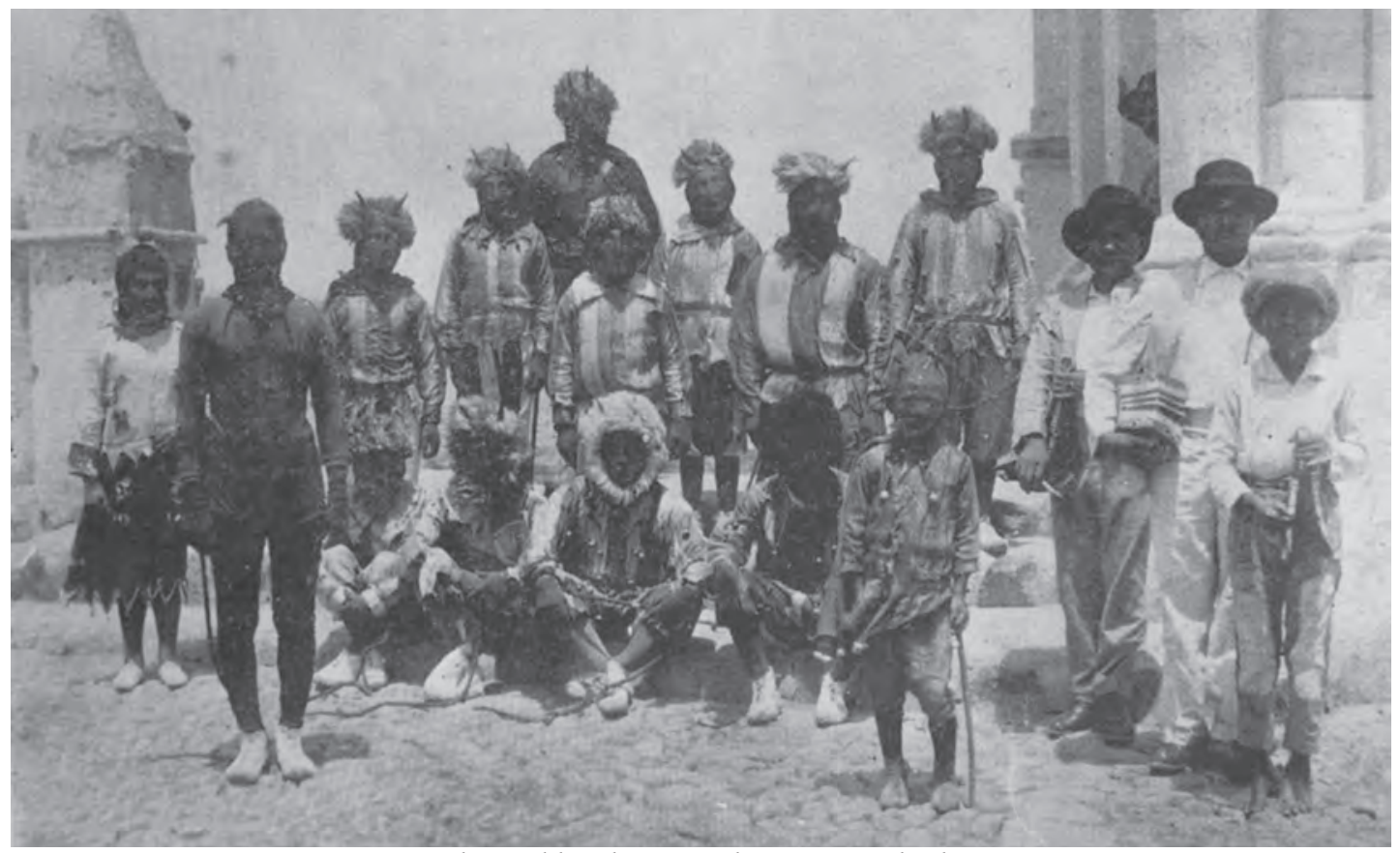

Figura 11. La Danza de Diablos de Huanchaco. Tomada de Jimenez Borja 1937. Es la fotografia más antigua conocida de esta danza

La actual danza de los Diablos de Huanchaco fue creada a finales del siglo XIX. Según las versiones locales, esta fue creada a iniciativa de un grupo de señores que no eran huanchaqueros. Estos vinieron de diferentes partes del país para trabajar en la entonces pudiente empresa de los Hermanos Larco, quienes tenían en Huanchaco el puerto para sus exportaciones e importaciones. La memoria colectiva ha guardado los nombres del Señor Filomeno Arzola, un señor de apellido Quesquén y otro de apellido Villalba quienes junto con otros cinco fundaron e iniciaron la danza de los Diablos de Huanchaco. Anecdóticamente, se formó este grupo no para danzar a la Virgen del Socorro, sino para la festividad del Señor del Nazareno del valle de Chicama. En aquella ocasión, salieron ocho danzantes. Posteriormente empiezan a participar en las Bajadas Quinquenales lo cual debió suceder entre 1900 y 1930 . Aparentemente, en la primera bajada salieron 10 o 12 diablos. Hacia 1930 los señores Víctor Beltrán y Guadalupe Ucañán, ambos huanchaqueros, comandaban junto con los fundadores, la danza de diablos.
Hoy en día, la danza solo participa cada cinco años en las fiestas del Huanchaquito o Bajadas del Socorro. La danza está conformada actualmente por un número ilimitado de danzantes que son comandados por un "Diablo Capataz" o "Diablo de Capa". Otros personajes son la "Diabla" que es considerada el "adorno" de la danza y que es un hombre disfrazado de mujer. También hay "Diablos Calatos" con disfraces de color negro o rojo. Algunos niños de corta edad (desde los 4 o 5 años hasta 8 o 10 años) se les llaman "Diablicos" y participan activamente en las coreografías de la danza. El resto son considerados "Diablos de Fila" y conforman el grueso de la comparsa. Cabe destacar que en la reciente festividad del año 2010, danzaron 400 diablos (Figs. 12, 13 y 14).

Portando sus vistosos trajes y características máscaras, al compás de la música de una quijada y concertina, la danza de Diablos de Huanchaco tiene el objetivo escénico de mostrar el triunfo del bien sobre el mal, graficado por la imagen del Arcángel San Miguel, quien no deja que los diablos se aproximen a la imagen de la Virgen 


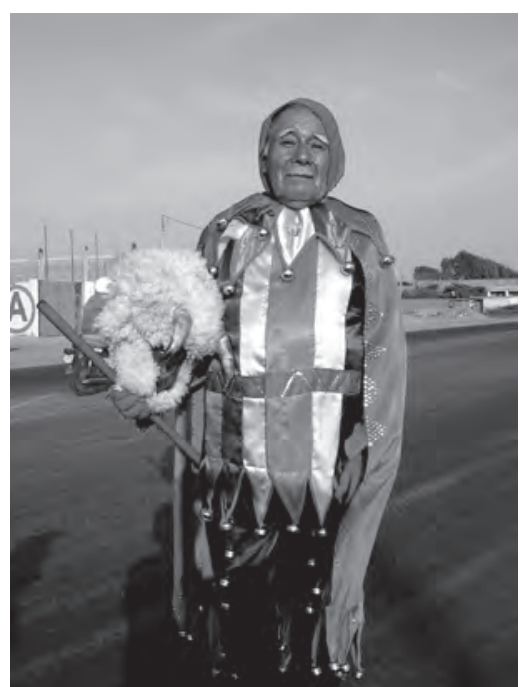

Figura 12. Diablo capataz, don José Leyton, uno de los más antiguos danzantes

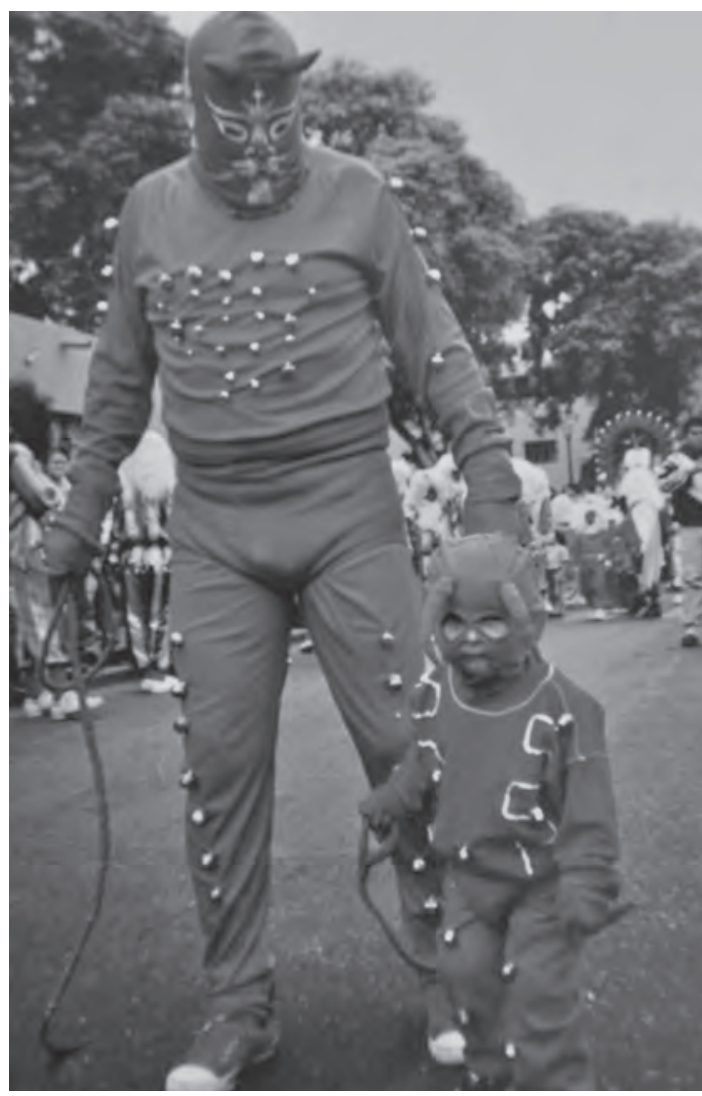

Figura 14. Diablo Calato Rojo y su diablico (Cortesía de la familia Arzola).

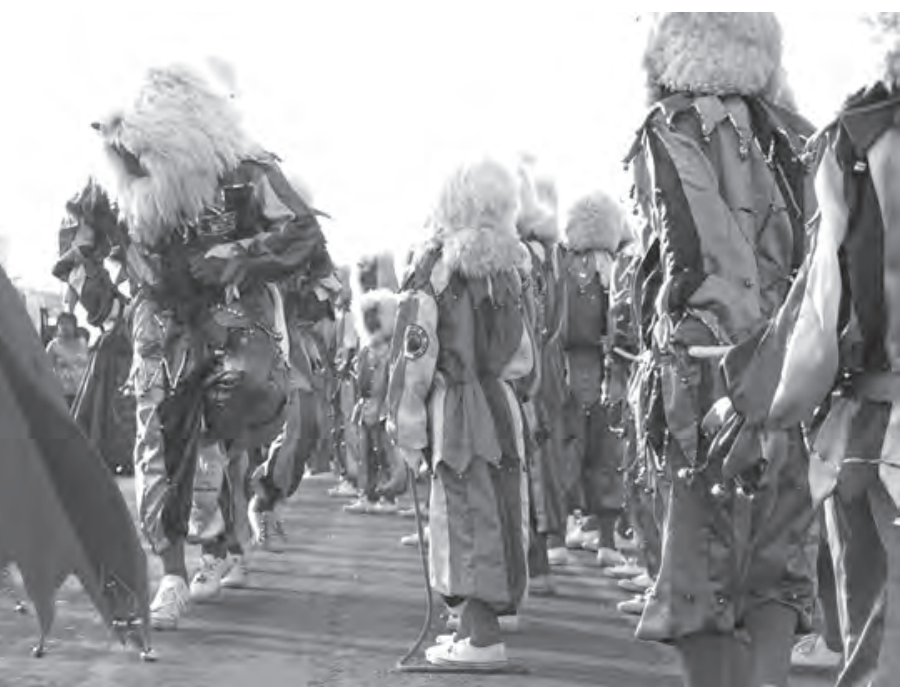

Figura 13. Diablos de Fila ejecutando su danza

Candelaria del Socorro de Huanchaco (Fig. 15). Por otro lado tienen un doble objetivo funcional: el primero es abrir paso entre las multitudes para que la imagen se desplace triunfante en su recorrido; el segundo es cuidar a la imagen durante su estadía en Trujillo, pues se tiene la reiterada creencia que puede ser robada.

Hasta la Fiesta del Huanchaquito del 2005, existían cinco agrupaciones de danzas: la del señor José Leyton Beltrán; la del señor José Arzola, la del señor Carlos Sánchez, la del señor Carlos Gordillo y la del señor Aurelio Gamarra.

\section{La Danza de las Pallas o Chinas}

Se desconoce la antigüedad de la Danza de las Pallas en Huanchaco, siendo probablemente una adición relativamente reciente (finales del siglo XIX e inicios del siglo XX), sin embargo es una danza extendida en la costa peruana desde el virreinato (Schaedel 1989: 175). Antiguamente se les conocía como las "Chinas" y su traje era distinto (Fig. 16). Hoy visten atuendos tipo vestidos cerrados largos de color celeste y franja blanca para el recorrido, mientras que el día central visten de color blanco. En ambos casos portan en la cabeza coronas de flores blancas (Fig. 17). Hasta mediados del siglo XX vestían a manera de huanchaquera, con 


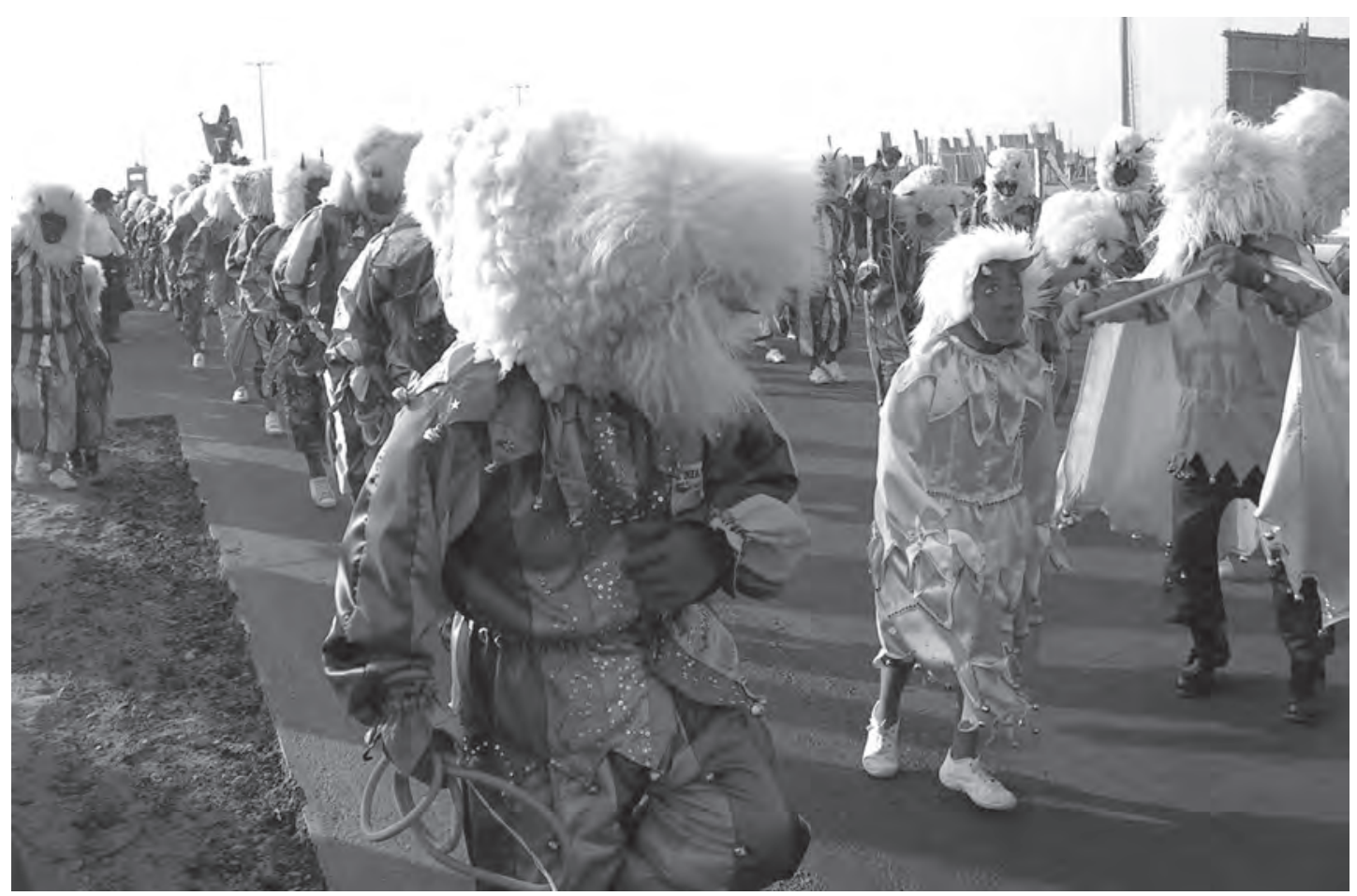

Figura 15. Nótese al fondo la imagen de San Miguel cuidando que los diablos no se acerquen a la imagen de la Virgen.

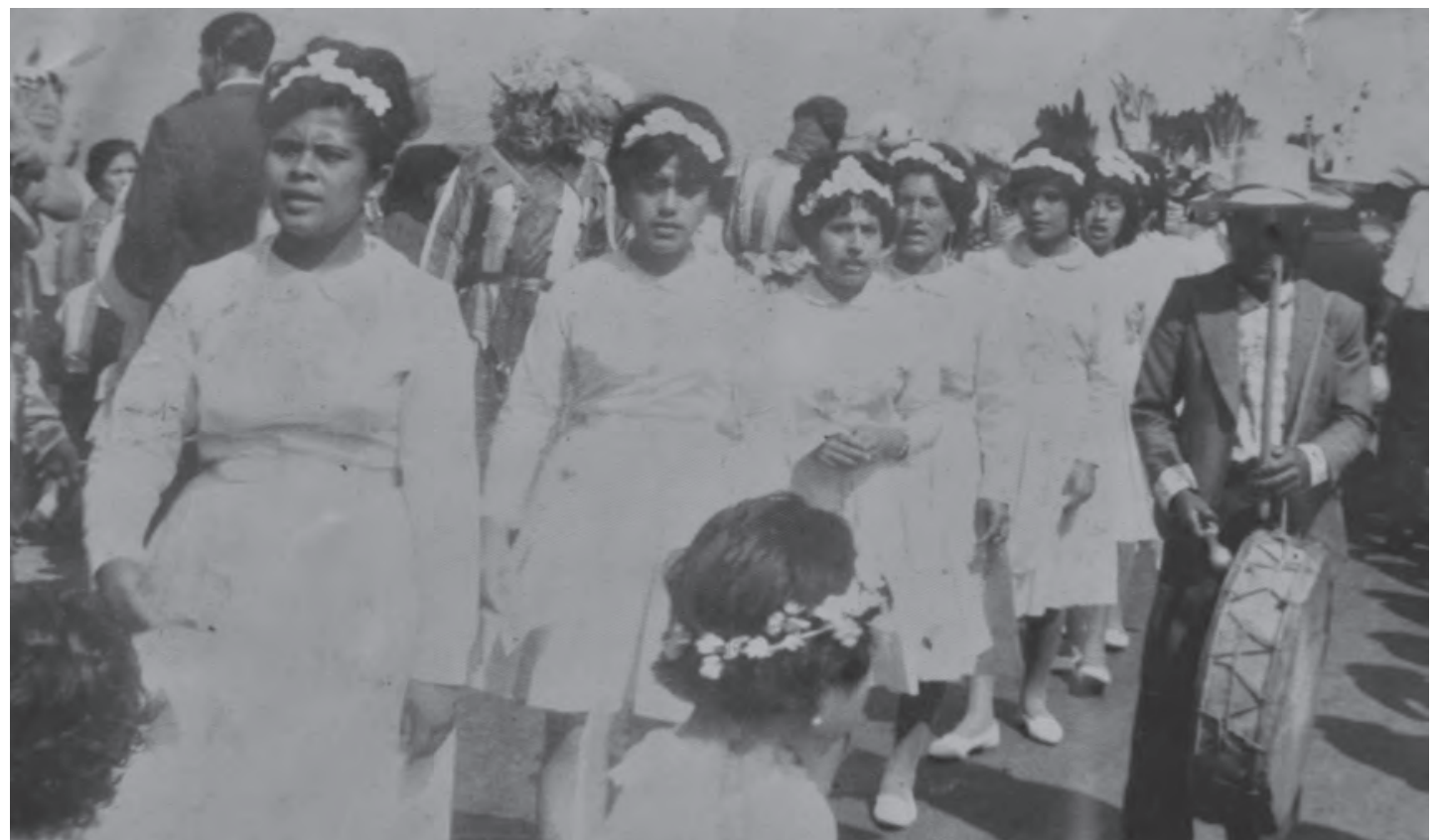

Figura 16. Pallas de la fiesta de 1950

(Cortesia de la familia Arzola). 


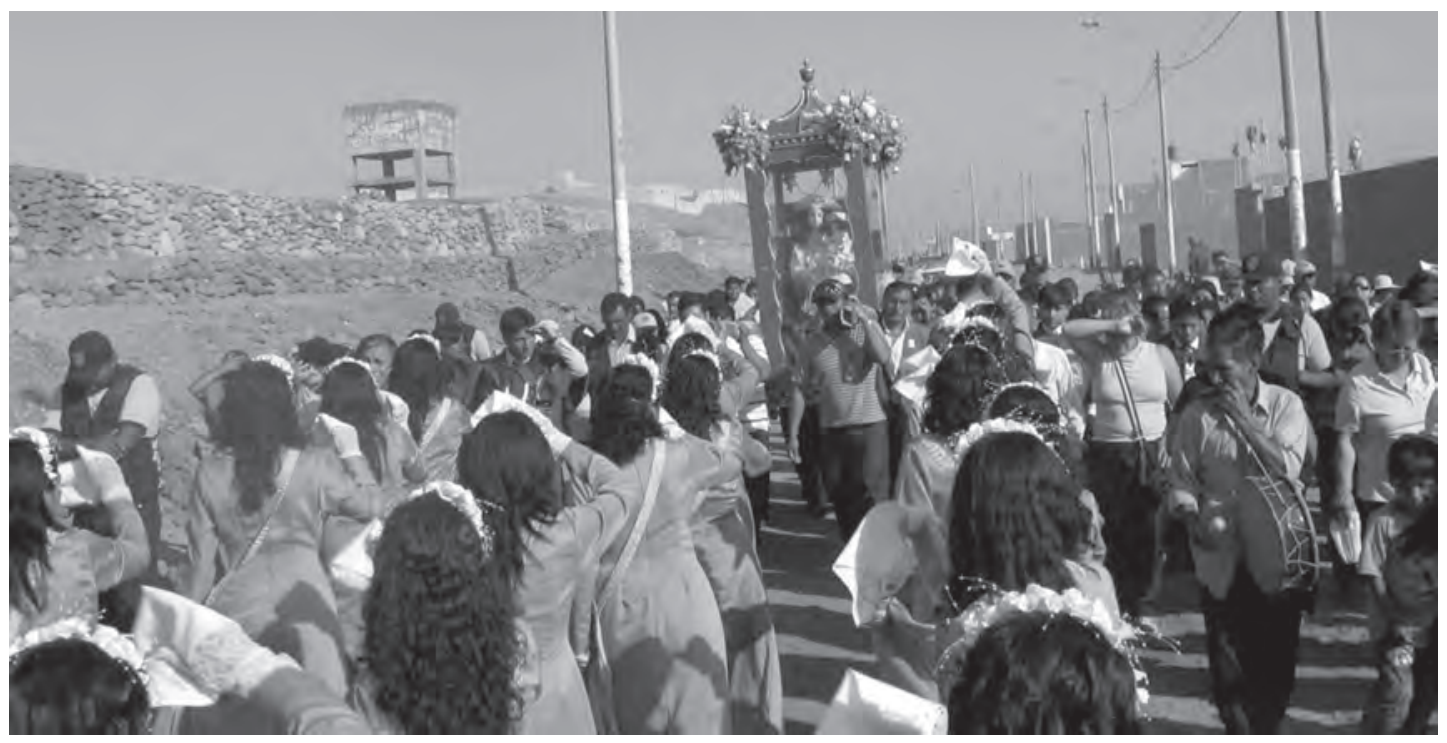

Figura 17. Las Pallas en la fiesta de 2010.

Nótese que nunca dan la espalda a la imagen de la Virgen

blusa rosada y falda tradicional de color negro con sombrero de paja. Las Pallas son jovencitas vírgenes cuidadosamente seleccionadas que oscilan entre los 15 y 20 años de edad. Ellas se encargan de cantar una larga lista de cuartetos (más de 150), los cuales están agrupados y dirigidos de acuerdo a la ubicación en que se encuentra la procesión de la imagen de la Virgen. Ellas siempre están ubicadas frente a la litera de la imagen, dando la espalda a la orientación del recorrido (Fig. 17). Pañuelo blanco en mano, y siguiendo algunos pasos que recuerdan movimientos suaves de la marinera antigua, las Pallas efectúan simples coreografías para "distraer" a la madre de Dios. Uno de los aspectos más interesantes es que casi todo el recorrido lo hacen caminando de espaldas, por lo que deben mantener una concentración muy estricta para coordinar su baile y canto.

Su preparación comienza en febrero, luego de finalizada la festividad anual de la Virgen Candelaria del Socorro de Huanchaco (García 2001). Sus preparadoras se encargan que memoricen en principio, y luego que den las entonaciones apropiadas para cada cuarteto. Estas señoritas, ofrecen su pureza a la madre Santísima y se consagran a ella hasta el día de su matrimonio, donde ofrecen que sus futuros hijos bailaran en las danzas que enaltecen el culto a esta imagen.

\section{Danzas Invitadas o Periféricas}

Existen dos danzas más en la actual Fiesta del Huanchaquito, las cuales pueden ser consideradas "periféricas" pero no por ello menos importantes. Se desconoce cuando empezaron a interactuar en esta festividad. Una de ellas no es de origen local. Se trata de la "Danza de los Indios de Santiago de Cao" quienes vienen exclusivamente a Huanchaco a despedir (al inicio de la fiesta) y a recibir (a su retorno de Trujillo) a la Virgen Candelaria del Socorro de Huanchaco. Esta es una pequeña danza conformada por individuos masculinos que lucen vistosos trajes en los que prevalecen grandes plumas de aves marinas. Ellos danzan durante la misa de despedida en el atrio del Santuario de Nuestra Señora Candelaria del Socorro de Huanchaco y cuando la imagen está a punto de abandonar el Santuario, los danzantes entran y se arrodillan ante la imagen, saludando y luego pidiendo su bendición (Fig. 18). Renombrados antropólogos, entre ellos José Sabogal Wiesse, han enfatizado la relación social y económica entre las comunidades vecinas de Huanchaco y Santiago de Cao (Sabogal 1974). El primer pueblo es de pescadores-mariscadoresagricultores y el segundo de agricultores-pescadores-cazadores y recolectores. Cabe indicar que ambas poblaciones se encuentran en los límites 


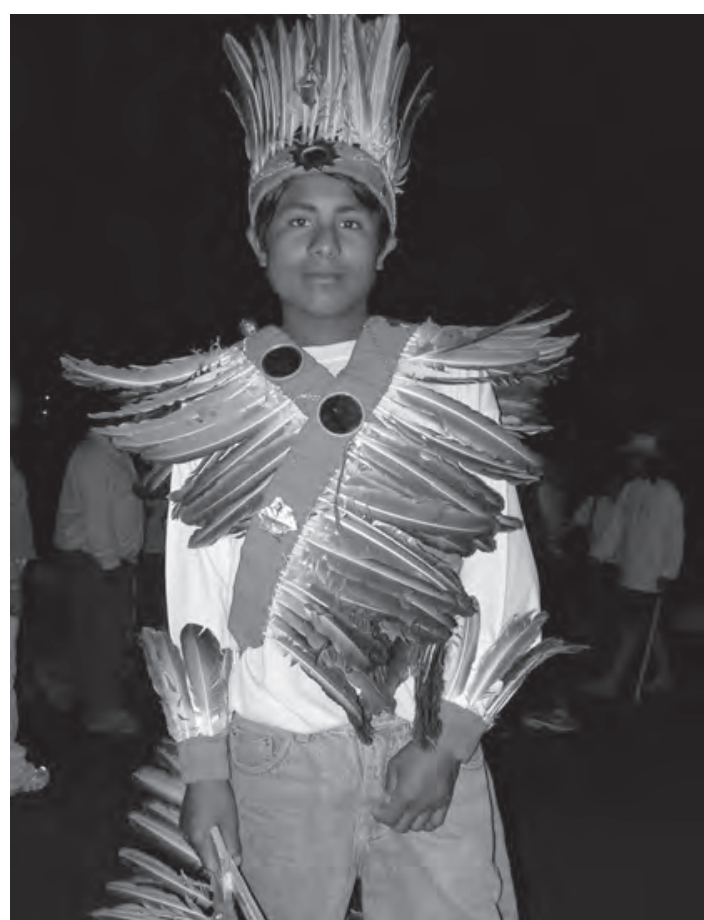

Figura 18. Danzante de la danza de los Indios de Santiago de Cao, en la fiesta del 2005

de sus respectivos valles. Por un lado Huanchaco es la última población tradicional en el extremo norte del valle de Moche, mientras que Santiago de Cao es la primera población tradicional en el extremo sur del valle de Chicama. Ambas pobla- ciones están separadas por el cerro Campana y el desierto de los alrededores. Así, se puede entender la conexión no solo geográfica, sino también económica y religiosa entre ambas poblaciones. La "Danza de los Indios de Santiago de Cao" también participan en la última pascana de regreso entre Huanchaquito bajo y Huanchaco el día 24 de diciembre.

La otra danza participante si es de origen local y es la denominada "Danza de los Negritos de Catamblá", que participa en la festividad huanchaquera anual de la "Fiesta del Niño Manuelito.” Ellos se concentran en la entrada del Pueblo de Huanchaco para recibir a la Virgen Candelaria del Socorro de Huanchaco. Generalmente se reúnen desde las 4 o 5 de la tarde y tienen la función de distraer al público con sus ocurrencias (Fig. 19). Al mismo tiempo, esperan a su patrón, el Niño Manuelito, quien llega en brazos de la Santísima Virgen para iniciar las festividades en su honor.

Dos Fiestas, DOS HISTORIAS, DOS OBJETIVOS, UN SOLO PUEBLO

En esta breve descripción de dos fiestas tradicionales del pueblo de Huanchaco, pretendemos llamar la atención sobre el abundante material etnográfico disponible para estudiar las socieda-

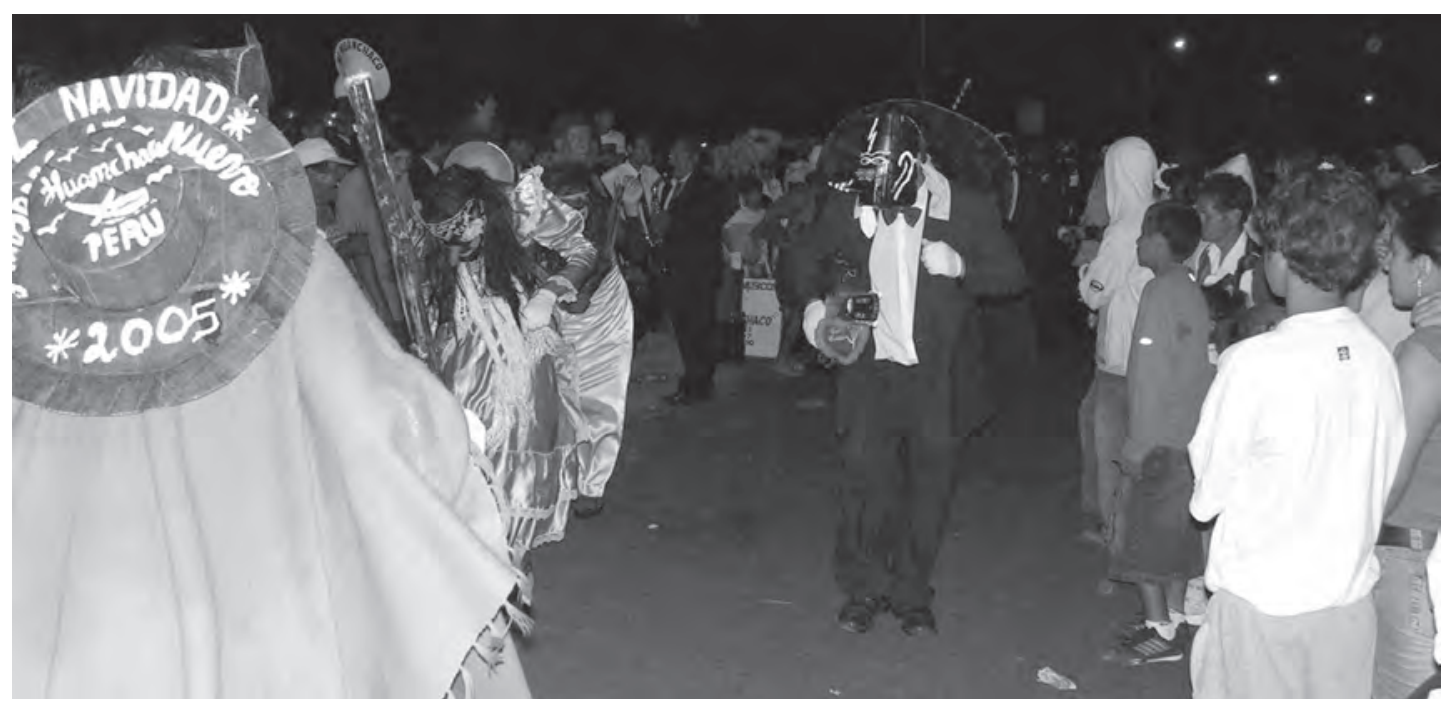

Figura 19. Los Negritos de Catambla salen a recibir a la imagen el 24 de diciembre 
des tradicionales actuales de la costa norte del Perú. Por otro lado tenemos el objetivo que la descripción e interpretación ofrecida aquí sirva como material de discusión para retomar los debates iniciados por María Rostworowski en la década de los ochentas sobre la mitología y estructuras religiosas e ideológicas de las sociedades andinas costeñas. Como hemos venido indicando y tomando las previsiones del caso, este material (y el enorme corpus aún no descrito sobre las fiestas locales de los pueblos costeros) ofrece una alternativa y una evidencia explicativa para los contextos arqueológicos que se vienen trabajando masivamente en los últimos años.

Los lectores habrán podido apreciar que en el caso de la fiestas anuales de la Virgen del Socorro, se ha tomado un mayor interés en describir y hacer paralelos así como interpretaciones sobre posibles escenarios ceremoniales en el pasado.
Es muy posible que estemos ante un caso en el cual queda claro que la Virgen representa el culto prehispánico al mar, lo cual fue una tradición pan-costeña que puede ser confirmada por la arqueología, etnohistoria y la etnografía moderna. En el caso de la segunda fiesta, su contexto histórico deriva más del dinamismo propio del virreinato, pero su recorrido y significados tienen algunas reminiscencias propias del pueblo huanchaquero y por lo tanto alguna tradición prehispánica antigua. No obstante, queremos llamar la atención que la visita de la imagen de la Virgen a Trujillo, si bien es cierto se enmarca correctamente en las tradiciones católicas de ese entonces, no debemos olvidar que las peregrinaciones no solo de pobladores sino de las huacas o divinidades andinas hacia los centros de poder político y religioso de la región, era una práctica común en el mundo andino prehispánico (Silverblatt 1987). Por lo tanto, proponemos

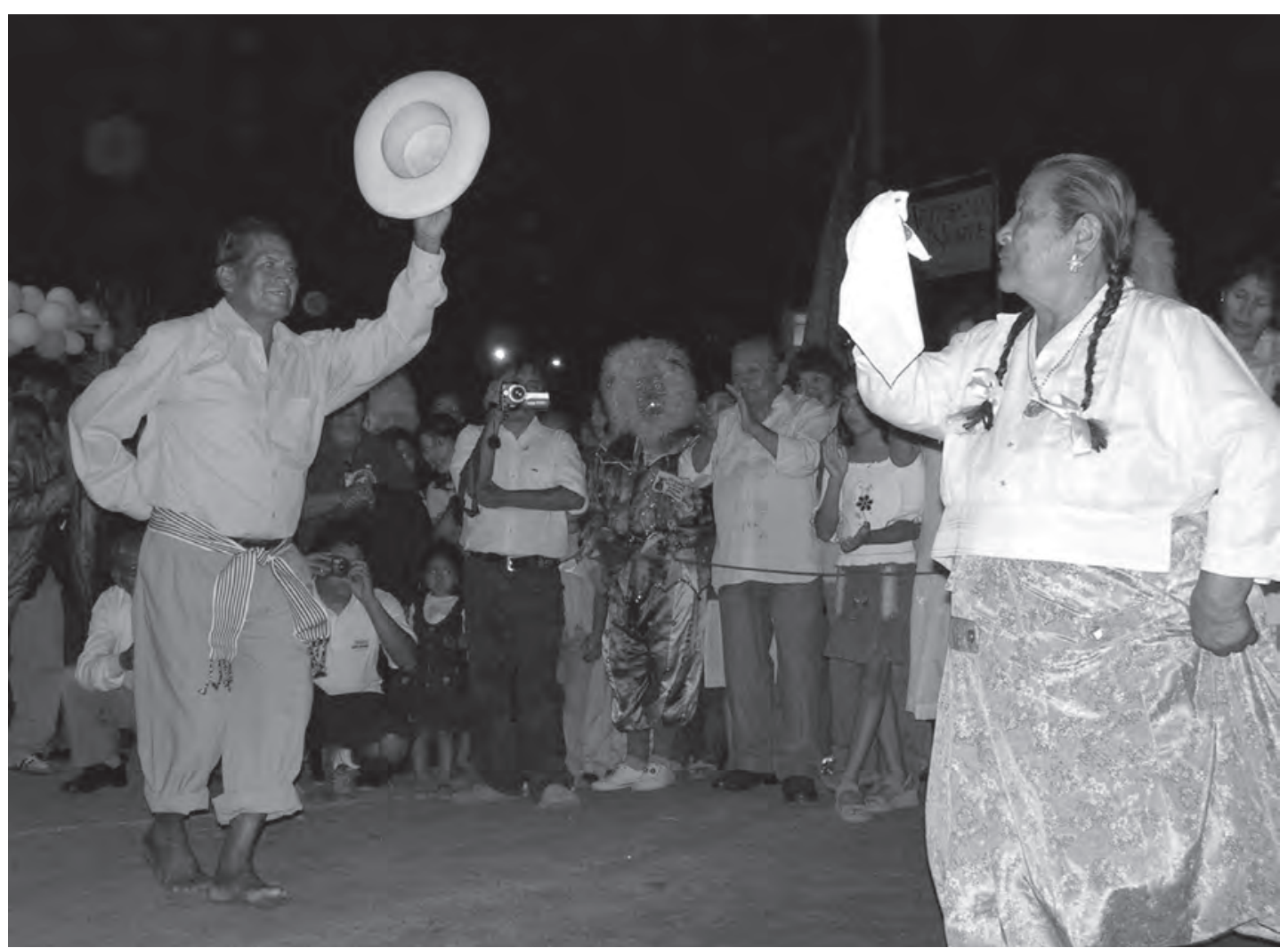

Figura 20. Huanchaqueros bailando marinera a la llegada de su patrona el 24 de diciembre de 2005. 
que al igual que se ha planteado para el caso de las visitas que varias divinidades realizaban a la ciudad de Cuzco, lo mismo pudo ocurrir durante el periodo Intermedio Tardío en la ciudad de Chan Chan, capital política y religiosa de la cultura Chimú. Si este fue el caso, entonces queda abierta la discusión si es que la capilla de San José, fue deliberadamente construida por las autoridades eclesiásticas del arzobispado de Trujillo en medio de una plaza de la ciudad Chimú con el objeto de acomodar y reinterpretar ciertas creencias y reminiscencias de festividades religiosas entre los pobladores de Huanchaco (Schaedel 1989: 166). Varios cronistas españoles y posteriormente viajeros del siglo XIX, refirieron a las prácticas idolátricas de los pescadores de Huanchaco incluso en pleno siglo XIX (Calancha 1974; Feijoo de Soza 1763; Lequanda 1793; Mellet 1971; Wiener 1993). Por lo tanto, es posible argumentar que a mediados-finales del siglo XVII los pobladores de Huanchaco tenían más arraigadas sus costumbres paganas. Por esta razón, la construcción de esta capilla en medio de la ciudad de Chan Chan es significativa (Schaedel 1989). Otro aspecto digno de comentar es que la primera parada de la imagen en la ciudad de Trujillo fue en la Iglesia de Santa Ana, donde según consta en archivos documentales se enterraron a varios curacas del valle. Por esta razón, resulta interesante que además del significado religioso, se haga una parada en el espacio donde se sepultó a los últimos señores de la diezmada sociedad Chimú. Quisiera enfatizar que esto se dio en una especie de complicidad con los religiosos españoles, quienes fueron flexibles y al mismo tiempo desarrollaron magistralmente la fusión de creencias locales con sus propios objetivos evangelizadores y políticos.

Hoy en día, en la primera década del siglo XXI, aún se pueden ver algunas reminiscencias de esa compleja fusión, lucha de poderes y amalgamientos culturales. Quizá estemos en el umbral de una nueva época, en la que esta fusión se está compactando de tal manera que tendrá próxi- mamente su propio rostro. Queda entonces por parte de los investigadores de las ciencias sociales apurar la pluma para registrar en los próximos años los últimos rezagos de esas singularidades, conflictos, tradiciones, leyendas, formas de vida y creencias religiosas que muy posiblemente terminen con la generación de los pobladores que hoy tienen entre 60 y 100 años de edad. En el camino podremos usar esta información para darle vida a nuestros contextos arqueológicos que solo se debaten, hoy por hoy, en modelos teóricos y procesos sociales que a decir verdad, no son tan distintos de otros propuestos en el resto del mundo.

\section{Agradecimiento}

Este artículo está dedicado a la memoria de don Mercedes Díaz, gran pescador y conocedor del pasado de Huanchaco. Asimismo quiero agradecer a mi abuela, la Sra. Lilette Burmester por inculcar en mi las leyendas y la búsqueda de la identidad de Huanchaco y su gente. Quiero agradecer también al Sr. Antonio Fernández por su constante ayuda en mis investigaciones etnográficas, así como a los Srs. Percy Valladades Huamanchumo, Elias Rodrich, Maria Elena Burmester, Pedro Anhuamán, Enrique Huamanchumo y a tantos otros que han contribuido de una u otra manera a recopilar información etnográfica de Huanchaco. Un tributo especial merecen Pedro Arroyo y Margarita Venegas quienes buscan recobrar las tradiciones de Huanchaco a través de sus festividades religiosas. Del mismo modo, quiero agradecer al alcalde de Huanchaco, Ing. Fernando Bazan Pinillos, por su invaluable apoyo para el reforzamiento de la identidad tradicional de este pueblo. Finalmente quiero agradecer a las familias huanchaqueras Díaz, Leyton, Arzola, Gordillo, Villacorta, Venegas, Ucañán, Piminchumo, Huamanchumo, Anhuamán, Segura, Verna y Chilmaza por su gentileza al permitirme entrevistarlos y conocer más sus tradiciones. 


\section{AneXo}

Leyenda de la llegada de Nuestra Señora Candelaria del Socorro de Huanchaco (Versión de Don Mercedes Díaz en febrero de 2001)

"Fue traída la Virgen de España. En una barca que venía a vela, y la Virgen lo hicieron en España, lo echaron en un cajón y lo encerraron, lo embarcaron en la barca y la barca se vino acá a Huanchaco.

Fue la Virgen del Socorro y el Sr. De Huamán. Ese señor de Huamán está allá al lado de Buenos Aires. El Señor de Huamán es de España.

Aquí dicen que los tripulantes de la barca ya pasaban meses y no conseguían tierra. Los tripulantes ya se aburrían contra el patrón y el timonel y lo querían tomar ya al patrón, para tomarle preso en el mismo barco, por lo que no conseguían tierra. Entonces el timonel lo decía que hay que tener paciencia, hay que tener paciencia! Que poco a poco tenemos que llegar a tierra. Esa paciencia fueron varios días, meses, y entonces uno de ellos, alcanzaron a ver unos pájaros en la mar, y por los pájaros que veían, entonces dijeron que se trataba de costa. $Y$ por los pajaritos vinieron, vinieron y se llegaron aquí a tierra.

Aquí llegaron; la barca se fondeo al frente. Aquí habían unos pescadores de antes, de los gentiles, y vieron que la barca estaba fondeada. Entonces esas gentes salieron en sus patachos, a ver a la barca que cosa es lo que quería y que cosa tenía. Entonces allí la gente que tenía la barca les dijo a la gente que se acercó, a los pescadores, que se hicieran unos grandes patachos, anchos, elevados, para que llegaran allá a la barca que querían desembarcar la Virgen que venía.

Era un cajón grande. Así que la gente se vinieron e hicieron el patacho. Una vez que hicieron el patacho se jueron allá al barco por medio de los cables que tiene y lo agarraron y lo levantaron al cajón para trasladarlo al patacho. El mar en ese tiempo dicen, estaba bravo, pero por desembarcar el cajón, se puso lagunita el agua.

Por donde se desembarcó la Virgen? ese muelle que se ve allí, no había. Se desembarcó del muelle pa'aca arribita (al sur del muelle). Allí era la parte más mansa. Hasta la orilla varó el patacho y sacaron al cajón. Sacando el cajón, lo sacan a la Virgen y lo llevan allá a la capilla, porque no había iglesia. Ya en la playa, le curo de la ceguera a una chinita que por-hay andaba.

Al día siguiente, va la gente a verlo y se da con que no había la Virgen. Quien se lo ha llevado! Lo buscaron, lo buscaron y no encontraban nada. No se cómo pasaba por acá por el cerro chico unos mercaderes que iban al norte a vender su mercadería y vieron a una señora que estaba alli en el cerro, con una criaturita. Así que esos mercaderes vinieron acá y avisaron en Huanchaco y jueron a verlo. Y era la Virgen que estaba en un recoveco a la parte de acá arriba (al sur) que estaba en un placercito de sombra. En el mismo cerro se había hecho un hueco y alli tenía un pocito con agua y era la Virgen.

Agarraron lo trajeron, lo pusieron a la capilla. Al otro día, vuelta la Virgen no había. Entonces, como ya sabían a donde estaba, se jueron a verlo allá y la encontraron vuelta. En ese entonces se presenta un padre que venía de rodillas, andando de Trujillo pa' aca. Ese padre no era de acá, era de España $y$ desde España dice que había salido mucho antes que la Virgen de pueblo en pueblo, de pueblo en pueblo hasta llegar a Trujillo. De Trujillo paso aquí a Huanchaco. Aquí en Huanchaco supo de una Virgen que no quería estar en su pueblo, que se iba a un cerro. Fue a traerlo el padre con su gente. Y lo puso acá. Al otro día, vuelta allá al cerrito se fue la Virgen.

Entonces el padre dijo: la Virgen no quiere estar acá, la Virgen quiere su iglesia, por eso es que uno la va a traer y se regresa, asi que hay que hacerlo su iglesia. El mismo se puso a hacerlo la iglesia, con toda la gente que llamó. Esa es la iglesia que está allí.

Una vez que ya lo compuso todo, agarró y lo fueron a traer, lo pusieron en su trono donde lo había hecho, su asiento para que fuese la patrona. Desde esa altura alcanzaba a ver los barcos, todos los barcos que pasaban en altura. Y desde allá se ve hasta acá.

Y así ha sido, nos contaban nuestros padres..." (versión de Don Mercedes Diaz ${ }^{+}$) 


\section{Bibliografía}

Alva Mendo, J.

2005 "Naufragios, aparecidos y marcas en la memoria de los pescadores huanchaqueros". Derroteros de la Mar del Sur 13, 9.17.

Alva, I.

2009 "Los Complejos de Cerro Ventarron y Collud-Zarpan: de Preceramico al Formativo en el valle de Lambayeque". En Peter Kaulicke y Yoshio Onuki, editores, Boletin de Arqueologia PUCP 12. Periodo Formativo: enfoques y evidencias recientes. Cincuenta anos de la Mision Arqueologica Japonesa y su vigencia. Primera Parte (pp. 97-117). Chiclayo: Pontificia Universidad Catolica del Perú.

Alva, W.

1999 Sipan: Descubrimiento e Investigacion. Lima, Perú: Fundacion Telefonica del Perú.

Alvarez Blas, J.

2004 Dioses y Hombres de la Libertad. Trujillo, Perú: Ediciones Viajeros.

Anhuaman, P.

2008 Cultura Viva Muchik-Chimor de la Costa Norte del Peru. Hisotria, Tradiciones, Leyendas y Personajes. Una Vision endogena. Trujillo, Perú.

Arguedas, Jose Maria y Pierre Duviols

1966 Dioses y Hombres de Huarochiri: Narracion quechua recogida por Francisco de Avila. Lima, Perú: Instituto Frances de Estudios Peruanos.

Blanco, L.

1994 "Las Monjas de Santa Clara: el erotismo de la fe y la subversion de la autoridad sacerdotal". En Luis Millones y Moises Lemlij, editores, En el Nombre del Senor. Shamanes, demonios y curanderos del norte del Peru (págs. 184-198). Lima, Perú: Biblioteca Peruana de Psicoanalisis.

Burmester Landauro, C.

2000 La Marinera: el renacimiento. Trujillo, Perú: Ediciones El Buho.

Calancha, A. d.

1974 Cronica Moralizadora [1638]. Lima, Perú: Editorial de la Universidad Nacional Mayor de San Marcos.
Campana, C.

2008 "La Vida en Chan Chan: Representacion y Comunicacion". Revista del Museo de Arqueologia, Antropologia e Historia, Nro. 8, 11-22.

Carrillo y Ancona, C.

1949 La Civilizacion Yucateca o el Culto de la Virgen Maria en Yucatan. Merida, Yucatan: Dias Massa, imprimio.

Casas Roque, L.

1998 Fiestas, danzas y musica de la costa de Lambayeque. En e. Raul R. Romero, Musica, danzas y mascaras en los Andes. Segunda Edicion (págs. 299-337). Lima, Perú: Fondo Editorial, PUCP.

Castañeda, J.

ms Apuntes para la Historia del Puerto de Huanchaco. Trujillo, Perú: Manuscrito en posesion del autor.

Damian, C.

1995 The Virgin of the Andes: art and ritual in colonial Cuzco. Miami Beach, Florida: Grassfield Press.

Del Busto Duthurburu, J. A.

2006 Santa Rosa de Lima (Isabel Flores de Oliva). Lima, Perú: Fondo Editorial PUCP.

Diocesana, I.

1931 Monografia de la diocesis de Trujillo. Tomo Segundo. Trujillo, Perú: Imprenta Diocesana.

Donnan, C.

1978 Moche Art of Peru: Precolumbian symbolic communication. Los Angeles, California: Museum of Cultiural History, University of California Los Angeles.

Donnan, Christopher y Donna McClelland

1999 Moche fineline painting: its evolution and its artists. Los Angeles, California: UCLA Fowler Museum of Cultural History.

Elera, C.

1994 "El Shaman del Morro Eten: antecedentes arqueologicos del shamanismo en la costa y sierra norte del Peru”. En L. M. Lemlij, En el nombre del Senor. Shamanes, demonios y curanderos del norte del Peru (págs. 22-51). Lima, Perú: Biblioteca Peruana de Psicoanalisis. 
Feijoo de Soza, M.

1763 Relacion Descriptiva de la ciudad, provincia de Truxillo del Peru, con noticias exactas de su estado politico, escrita por el doctor don Miguel Feijoo en la imprenta del Real y Supremo Consejo de las Indias. Sevilla, España.

Fernandez de Cordova, P. A.

1818 Vida de la Gloriosa Santa Rosa de Santa Maria. Lima, Perú: Impresa en Lima. Calle de Bravo.

Fiedler, Reginald, Norman D. Jarvis y Milton J. Lobell

1943 La Pesca y las Industrias Pesqueras en el Perú. Lima, Perú: Compañia Administradora del Guano.

Flores Araoz, Jose, Ramon Mujica Pinilla, Luis Eduardo Wuffarden y Pedro Guibovich Perez

1995 Santa Rosa de Lima y su tiempo. Coleccion Arte y Tesoros del Perú. Lima, Perú: Banco de Credito del Perú.

Garcia Gutierrez de Barriga, C. R.

2001 Las Danzas de Diablos y Pallas en la Fiesta de la Virgen del Socorro de Huanchaco. Lima, Perú: Biblioteca Nacional del Perú y Pontificia Universidad Catolica del Perú.

Gillin, J.

1945 Moche: A Peruvian Coastal Community. Washington, DC: Smithsonian Institution. Institute of Social Anthropology. Publication Neo. 3.

Jimenez Borja, A.

1937 Moche. Lima, Perú: Editorial LUMEN, S.A.

Lanuza y Sotelo, E.

1998 Viaje Ilustrado a los Reinos del Peru, siglo XVIII. Lima, Perú: Fondo Editorial PUCP.

Lemlij, M.

1994 A Proposito de las monjas de Santa Clara: una mirada psicoanalitica. En Luis Millones y Moises Lemlij, En el nombre del Senor. Shamanes, demonios y curanderos del norte del Peru. (págs. 199-210). Lima, Peru: Biblioteca Peruana de Psicoanalisis.
León Barandiarán, A.

1938 Mitos, Leyendas y Tradiciones Lambayecanas. Contribucion al Folklore Peruano. Lima, Peru: Club de Autores y Lectores de Lima.

Lequanda, J. I.

1793 "Descripcion Geografica de la Ciudad y Partido de Trujillo". Mercurio Peruano, Tomo VIII.

Mackey, C.

2001 "Los Dioses que perdieron los colmillos". En K. Makowski, editor, Dioses del Antiguo Peru, Vol. II. Coleccion Arte y Tesoros del Peru Antiguo (págs. 111-157). Lima, Peru: Banco de Credito del Peru.

Malaga Nunez-Zeballos, A.

2000 Historia de la Virgen Candelaria en el Obispado de Arequipa. Siglos XVI-XX. Arequipa, Peru: Universidad Catolica Santa Maria.

Martinez de Compañon y Bujandan, B. J.

1978 La Obra del Obispo Martinez de Companon sobre Trujillo del Peru en el siglo XVIII. Madrid, España: Editorial de Cultura Hispanica.

Marzal, M.

1977 Estudios Sobre Religion Campesina. Lima, Peru: Pontificia Universidad Catolica del Peru.

McClelland Donna, Donald McClelland y Christopher Donnan

2007 Moche Fineline Painting from San Jose de Moro. Los Angeles, California: Cotsen Institute of Archaeology at UCLA.

McClelland, D.

1990 "A Maritime Passage from Moche to Chimu". En Michael Moseley y Alana Cordy-Collins, editores, The Northern Dynasties. Kinship and Statecraft in Chimor (pp. 75-106). Washington DC: Dumbarton Oaks, Trustrees for Harvard University.

Mellet, J.

1971 "Impresiones sobre el Peru en 1815". En Estuardo Nuñez, editor, Relaciones de Viajeros, Vol. 27, Tomo I. Lima, Peru.

Miller, George y Richard L. Burger

2000 Charki at Chavin: Ethnographic Models and Archaeological Data. American Antiquity 65(3), 573-576. 
Minaya, J. F.

2008 "Danza de los Diablos en el Peregrinaje de la Virgen de la Candelaria o Virgen del Socorro de Huanchaco". Revista del Museo de Arqueologia, Antropologia e Historia Nro. 10, 327-346.

Morgan, A.

1988 "The Master of Mother Fishes. An Interpretation of Nasca Pottery Figurines and their Symbolism”. En R. S. Archaeology, Nicholas J. Saunders y Olivier de Montmollin, editores (pp. 327-361). BAR International Series 421(ii).

Ortloff, C.

1981 "La Ingenieria Hidraulica Chimu (parte I): el sistema de canales La Cumbre". En H. L. Soldi, La Tecnologia en el Mundo Andino.

Paulsen, A.

1974 "The Thorny Oyster and the voice of God: Spondylus and Strombus in Andean Prehistory". American Antiquity 29(4), 597-607.

Prieto, G.

2008 "La Leyenda del Sr. de Huaman". Diario La Industria de Trujillo. 16 de noviembre.

Prieto, G.

s.f. Tiempo de Abundancia: un festival olvidado?

Prieto, Gabriel y Jesus Lopez

2007 Excavaciones en el Area 35 de San Jose de Moro. En Luis Jaime Castillo, Programa Arqueologico San Jose de Moro: Informe Tecnico de Excavaciones 2006. Lima, Peru: Pontificia Universidad Catolica del Peru.

Prieto, O. G.

2009 "Tres Aspectos Etnograficos del Pueblo de Huanchaco". Revista del Museo de Arqueologia, Antropologia e Historia 11, 277-306.

Recuenco Cardoso, C.

2007 Nuestra Marinera. Una reina de la identidad nacional. Trujillo, Peru.

Rodriguez Suy-Suy, V. A.

1997 Los Pueblos Muchik en el Mundo Andino de Ayer y Siempre. Moche, Peru: Centro de Investigacion y Promocion de los Pueblos Muchik "Josefa Suy Suy Azabache".
Romero Lostaunau, G.

2008 Apuntes Historicos de la Marinera, reina de las danzas del Peru. Lima, Peru: Centro de Producciones Graficas.

Romero, F.

1942 "De la Zamba de Africa a la Marinera del Peru". En Actas y Trabajos Cientificos del XXVII Congreso Internacional de Americanistas. Tomo II (págs. 105-140). Lima, Peru.

Rostworowski, M.

2004 Costa Peruana Prehispanica. Lima, Perú: Instituto Peruano de Estudios Andinos.

Sabogal Wiesse, J.

1974 "La Villa de Santiago de Cao, ayer. Narracion de don Enrique". Anuario Indigenista, Vol. XXXIV, 91-151.

Schaedel, R.

1989 La Etnohrafia Mucjik en las fotografias de H. Bruning 1886-1925. Lima, Peru: Ediciones COFIDE.

Schweigger, E.

1947 El Litoral Peruano. Lima, Peru: Compañia Administradora del Guano.

Silverblatt, I.

1987 Moon, Sun, and Witches. Gender Ideologies and Class in Inca and Colonial Peru. Princeton, New Jersey: Princeton University Press.

Trens, M.

1946 Maria. Iconografia de la Virgen en el Arte Espanol. Madrid, Espana: Editorial Plus Ultra.

Vargas Ugarte, R.

1947 Historia del Culto de Maria en Iberoamerica. Buenos Aires, Argentina: Editorial Huarpes, S.A.

Vasques, Guillermo, Ivo Manuel Lira Lopez y Marco Antonio Valderrama Zea

2002 Virgen de la Candelaria. Antologia de Ensayos sobre la Festividad. Tomo I. Puno, Peru: Punenidad, editores.

Wiener, C.

1993 Peru y Bolivia, Relato de Viajes. Travaux de'l Institute Francais d' Etudes Andines 56. Lima, Peru: Instituto Frances de Estudios Andinos y Universidad Nacional San Marcos. 